Discussion Paper 125

Institute for Empirical Macroeconomics

Federal Reserve Bank of Minneapolis

90 Hennepin Avenue

Minneapolis, Minnesota 55480-0291

December 1997

\title{
The Demand for Money by Firms: Some Additional Empirical Results*
}

\author{
Casey B. Mulligan \\ University of Chicago
}

\begin{abstract}
COMPUSTAT data on 12,000 firms for the years 1956-1992 indicate that large firms hold less cash as a percentage of sales than do small ones. Whether comparisons are made within or across industries, the elasticity of cash balances with respect to sales is about 0.75 . Firms headquartered in counties with high wages hold more money for a given level of sales, a finding consistent with the idea that time can substitute for money in the provision of transactions services. The estimates are consistent with both scale economies in the holding of money and secular declines in velocity.
\end{abstract}

*This research has benefitted from discussions with Gary Becker, Hiroshi Fujiki, Bob Lucas, Allan Meltzer, Derek Neal, Xavier Sala-i-Martin, and participants at the October 1994 NBER Monetary Economics meeting. The views expressed herein are those of the author and not necessarily those of the Federal Reserve Bank of Minneapolis or the Federal Reserve System. 


\section{Table of Contents}

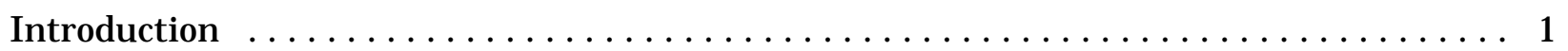

A Parametric Model of the Demand for Money by Firms $\ldots \ldots \ldots \ldots \ldots \ldots \ldots \ldots$

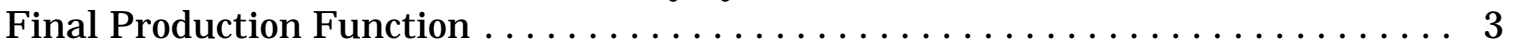

Production of Transactions Services $\ldots \ldots \ldots \ldots \ldots \ldots \ldots \ldots \ldots \ldots \ldots \ldots \ldots \ldots$

Cost Minimizing Demand for Money $\ldots \ldots \ldots \ldots \ldots \ldots \ldots \ldots \ldots \ldots \ldots$

Scale Economies and Secular Trends in Velocity .................... 7

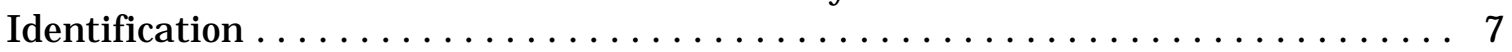

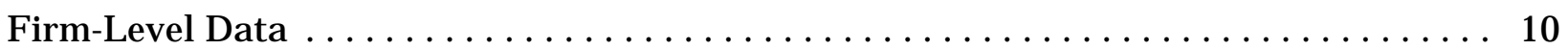

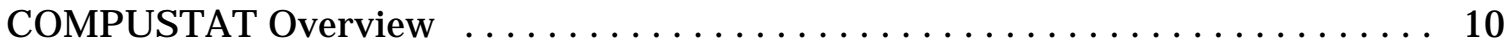

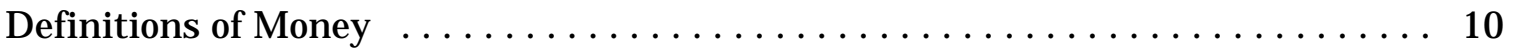

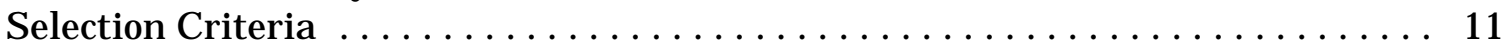

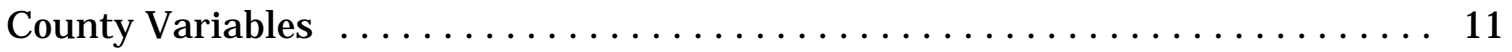

Estimates of the Demand for Currency and Demand Deposits $\ldots \ldots \ldots \ldots \ldots \ldots \ldots, 12$

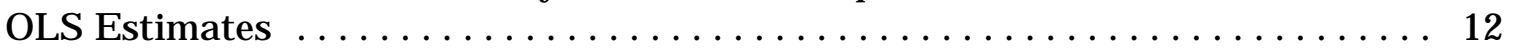

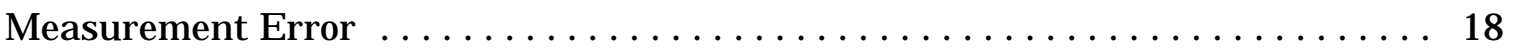

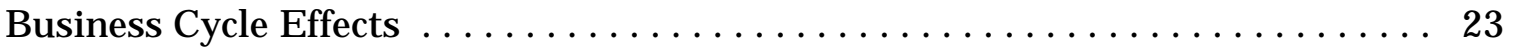

Selection Bias ...................................... 27

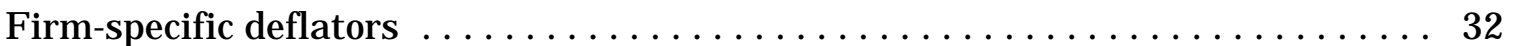

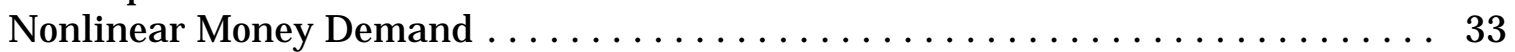

A Comparison with Earlier Studies of Firms $\ldots \ldots \ldots \ldots \ldots \ldots \ldots \ldots \ldots \ldots$

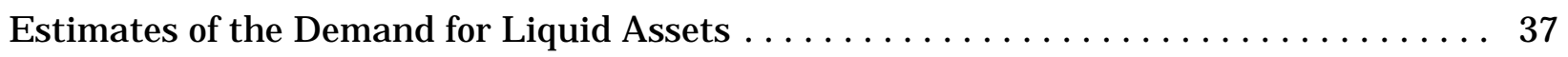

Implications for Aggregate Data $\ldots \ldots \ldots \ldots \ldots \ldots \ldots \ldots \ldots \ldots \ldots \ldots \ldots \ldots \ldots$

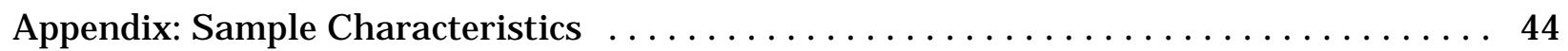

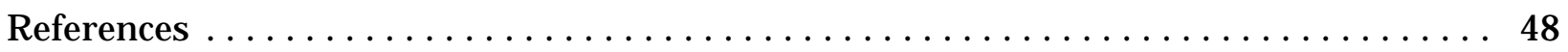




\section{Introduction}

A quantitative knowledge of the demand for money is necessary for predicting and explaining inflation and interest rates. Such knowledge may also be relevant for the branch of monetary theory which seeks to understand how and why money is such an important part of market transactions. Money is al so a fiscal tool: seignorage is an important source of revenue for many governments. Even for those countries with relatively slow monetary growth, the inflation tax may impose sizable burdens on the economy. Quantitative estimates of the demand for money - especially estimates of the degree of scale economies - are required to determine the socially optimal use of this fiscal tool. ${ }^{1}$

This paper estimates a parametric model of the demand for money by firms using longitudinal data on the sales, money holdings, and other variables at the firm-level. The firmlevel data indicate that there are economies of scale in the holding of money - the sales elasticity of money demand is found to be about 0.75 . There is also some evidence that time is a substitute for money - the elasticity of money demand with respect to a proxy for the cost of labor is about 0.75 .

The paper builds on Mulligan (1997) in three ways. First, parameters of the empirical model are linked to those of an explicit maximizing model of firm behavior. Second, the empirical specification in the present paper is much more realistic, allowing for price deflators that are a function of a firm's input and output prices, lags in the money demand function, firmspecific opportunity costs of holding money, nonlinear demand functions, and financial technology that varies according to urban location. Third, the model is estimated using a broader sample of COMPUSTAT firms.

I argue that cross-sectional studies of the demand for money enjoy a useful identifying restriction - the degree of financial sophistication is relatively constant across regions, firms, or households. Such a restriction is less plausible for time series data, where, during certain periods, there are secular trends in the level of financial technol ogy. NOW accounts, automatic

\footnotetext{
${ }^{1}$ See F aig (1988) and Mulligan and Sala-i-Martin (1996) for a proof that the degree of scale economies is an important determinant of the efficiency of the inflation tax from a Ramsey (1927) point of view.
} 
teller machines, and credit cards might be considered as modern examples.

This study is part of a small literature that uses cross-sectional data to identify the parameters of a money demand function. Included in that literature are Meltzer (1963a), Maddala and Vogel (1965), and Whalen (1965) who study cross-sections of industry aggregates, Feige (1964) and Mulligan and Sala-i-Martin (1992) who study cross-sections of regional aggregates, and Lee (1964), Radecki and Garver (1987), and Bomberger (1993) who study crosssections of households. Although these cross-section studies invoke different identifying restrictions than do time series studies, many problems remain. Regional and household data have the problem that the cost of substitutes for money (in particular, time) are highly correlated with the scale of operation. Different firms, on the other hand, may face different wages and other prices in a way that is uncorrelated with the scale of operation. Interstate banking complicates regional data and income measurement error plagues cross-sectional studies of households, but the longitudinal structure of the COMPUSTAT data allow me to ascertain the importance of various measurement errors.

Section II writes down and parameterizes a production function for firms. The demand for money is defined and related to the production parameters. The firm data is described in section III and used in section IV to estimate parameters of the production function. Section IV addresses the possibility that estimates of the scale and wage elasticities are biased as the result of the omission of proxies for production parameters, business cycle variables, price levels, or measurement errors. Section V compares firms' demand for the more narrowly defined "money" with the demand for liquid assets. Section VI discusses previous studies that have used aggregate data, comparing the aggregate estimates with the firm-level estimates here. An appendix displays some sample characteristics. 


\section{A Parametric Model of the Demand for Money by Firms}

\section{II.A Final Production Function}

The production or sales (I do not distinguish the two until Section IV) of firm i at date $t$, denoted $y_{i t}$, is a function of a $\mathrm{J}$-dimensional vector of inputs $X_{i t}$ as well as the quantity of transactions services used at date $t, T_{i t}$.

$$
y_{i t}=f\left(X_{i t}, T_{i t}, \theta_{i t}\right)
$$

where $\theta$ is technological shift parameter. For simplicity, I consider the case when there is one input $\left(J=1\right.$ ) and parameterize the function $\mathrm{f:}^{2}$

$$
\begin{gathered}
y_{i t}=f\left(x_{i t}+\theta_{i t}, T_{i t}\right)= \\
{\left[\left(1-\lambda_{f}\right)\left(x_{i t}+\theta_{i t}\right)^{\frac{\gamma-\beta}{\gamma}}+\lambda_{f}\left(\frac{\gamma-\beta}{\gamma-1}\right) T_{i t}^{\frac{\gamma-1}{\gamma}}\right] \frac{\gamma}{\gamma-\beta}} \\
\lambda_{f} \in(0,1), \quad \beta>0, \quad \gamma \in(0, \min (1, \beta))
\end{gathered}
$$

For $\beta=1$, transactions services are combined with $x+\theta$ in a CES fashion, with elasticity of substitution $\gamma$. However, production is not homogeneous for $\beta \neq 1$. As I show later, there are economies (diseconomies) of scale in the holding of money as $\beta<1(\beta>1)$. As the importance of transactions services becomes small relative to the other input $x$, the production function exhibits approximately constant returns to scale in $x+\theta$.

\section{II.B Production of Transactions Services}

Transactions services depend on real money balances held by the firm. Firms can enjoy more transactions services for a given stock of money by using certain types of capital and labor. For simplicity, I consider a single labor input but it is straight-forward to allow for other inputs into the production of transaction services.

${ }^{2} \mathrm{~J}=1$ is chosen for simplicity. The analysis could be generalized by replacing $\mathrm{x}$ with a homogeneous function many inputs (eg., several types of labor and several types of capital). 


$$
\begin{gathered}
T_{i t}=A_{i t}\left[\left(1-\lambda_{\phi}\right) m_{i t}^{\left(\psi_{\phi}-1\right) / \psi_{\phi}}+\lambda_{\phi} l_{i t}^{\left(\psi_{\phi}-1\right) / \psi_{\phi}}\right] \psi_{\phi} /\left(\psi_{\phi}-1\right) \\
\lambda_{\phi} \in(0,1), \quad \Psi_{\phi}>0
\end{gathered}
$$

$m_{i t}$ is the stock of real money balances held by firm i at date $t^{3}$ The quantity $l_{\text {it }}$ of labor is used by the firm to produce transactions services. The elasticity of substitution between money and labor is $\psi_{\phi} . A_{i t}$ is a productivity parameter reflecting, say, exogenous changes in the "financial sophistication" of the firm.

Some models of the demand for money suggest that money balances or transactions services are complements with the other inputs. ${ }^{4}$ This might be expressed in my model as a parameter restriction $\gamma<1$. That labor substitutes for money in the provision of transactions services can be represented as $\psi_{\phi}>1$.

\section{II.C Cost Minimizing Demand for Money}

It is assumed that firms rent inputs (including money and labor) so as to minimize the cost of production $\mathrm{c}_{\mathrm{it}}{ }^{5}$ Cost is the sum of the rental expenditures:

$$
c_{i t}=x_{i t}+w_{i t} l_{i t}+R_{t} m_{i t}
$$

where the rental cost of $\mathrm{x}$ is normalized to one. The rental rate of money is the nominal interest rate $R_{t}$ and is assumed to be the same for all firms. Different firms may rent labor at different wage rates, reflecting perhaps regional differences in the market for the type of labor needed to produce transactions services. Cost minimizing or derived demands for the four inputs are written as a function of the level of sales $y_{i t}$, the two prices $w$ and $R$ as well as the productivity parameter A. I denote the derived demand for money by the function $L$ :

${ }^{3}$ Section IV discusses the price index used to deflate nominal money balances and implications of the deflating method for interpreting the empirical results.

${ }^{4} \mathrm{~F}$ or a discussion of the relationship between "money in the production function" and apparently different motivations for the demand for money, see Fischer (1974), F eenstra (1986), or Fujiki and Mulligan (1996).

${ }^{5} \mathrm{~A}$ static cost minimization condition such as (3) holds in some intertemporal models. See Fujiki and Mulligan (1996) for an example. 


$$
m_{i t}=L\left(y_{i t}, R_{t}, w_{i t}, A_{i t}, \theta_{i t}\right)
$$

Imagine fixing a price vector and varying the level of sales, tracing out an expansion path in the $(x, I, m)$ space. This expansion path is a one dimensional manifold in a three dimensional space, but can be shown on paper by projecting it into the $(\mathrm{m}, \mathrm{x})$ plane. One such projection is shown in Figure 1.

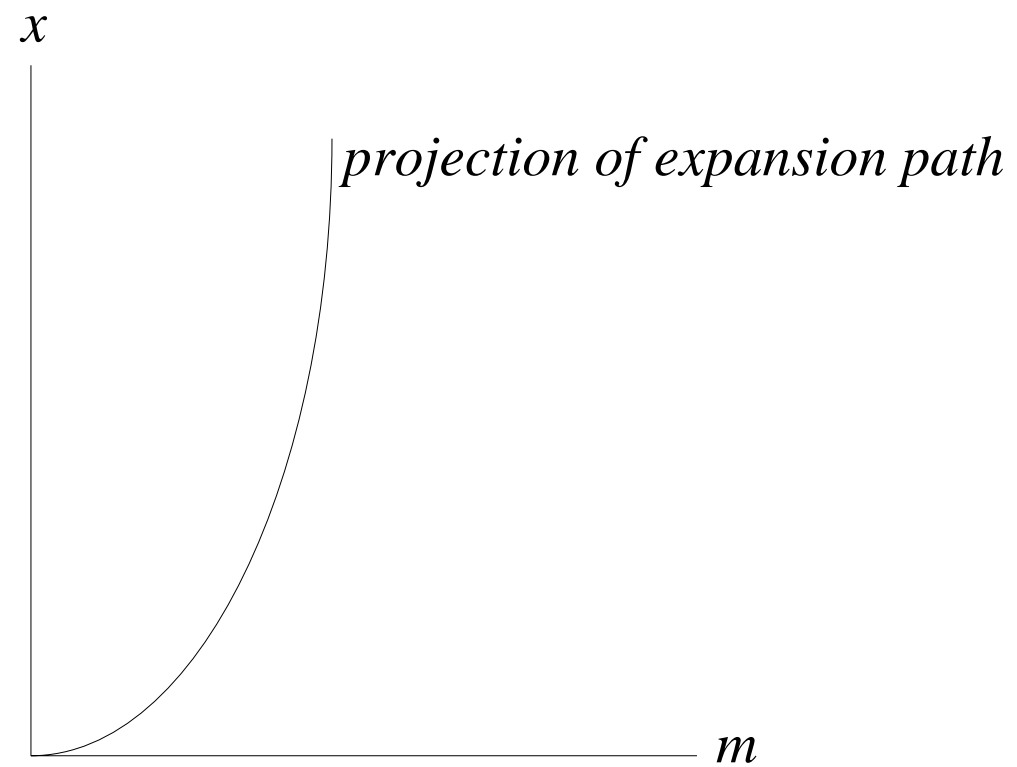

Figure 1 Projection of Expansion Path

The projection of the expansion path, denoted $g_{1}$, is formally defined in terms of the derived demand for money, $L$, and the derived demand for $x, H$ :

$$
m_{i t}=g_{1}\left(x_{i t}, R_{t}, w_{i t}, A_{i t}, \theta_{i t}\right) \equiv L\left(H^{-1}\left(x_{i t}, R_{t}, w_{i t}, A_{i t}, \theta_{i t}\right), R_{t}, w_{i t}, A_{i t}, \theta_{i t}\right)
$$

where $H^{-1}$ is the inverse of the derived demand for $x=H(y, R, w, A, \theta)$.

In general, the shape of the expansion path depends on the prices but for the functional forms (1) and (2), one can write money demand as a log-linear function of the demand for $x$, the 
prices, and productivity:

$$
\begin{aligned}
\log m_{i t}=\log g_{1}\left(x_{i t}, R_{t}, w_{i t}, A_{i t}, \theta_{i t}\right) & =\beta \log \left(x_{i t}+\theta_{i t}\right)-\gamma \log R_{t}+\pi_{\phi}\left(\Psi_{\phi}-\gamma\right) \log \frac{w_{i t}}{R_{t}} \\
& -(1-\gamma) \log A_{i t}+\varphi\left(\Psi_{\phi}, \gamma, \beta, \lambda_{f}, \lambda_{\phi}\right)
\end{aligned}
$$

$\varphi$ is an intercept term that is a function of the production parameters only. A projection of the expansion path into the $(m, x+\theta)$ plane has a constant elasticity equal to $\beta$. Holding constant $\mathrm{W} / \mathrm{R}$, the elasticity with respect to the nominal interest rate is the constant $-\gamma{ }^{6}$

Given $x$, increases in the level of financial technology, $A_{i t}$, decrease the demand for money when $\gamma$ is less than one, but increase money demand for $\gamma>1$. The effect of technology on the demand for money depends on the interest elasticity of money demand. To see this, notice that holding constant $w / R$, the price of transactions services is the ratio $R / A$. Transactions services are more costly when $w$ and $R$ increase, but are less expensive when $\mathrm{m}$ and I are more productive. $\gamma<1$ means that there are few possibilities for substitution of $T$ for $x$, so a change in R/A - say because of an increase in A - does little to the demand for $T$. The productivity effect of $A$ therefore dictates that the demand for $m$ and I fall. For $\gamma>1$, the substitution towards transactions services outweighs the productivity effect so the demands for $\mathrm{m}$ and $\mathrm{I}$ increase.

It is shown by Fujiki and Mulligan (1996) that, as money's share of cost $(\mathrm{Rm} / \mathrm{c})$ approaches zero (say, as $\lambda_{\mathrm{f}} \rightarrow 0$ ), the derived demand for money shares several properties with the expansion path (4)' shown above. In particular, the scale and own-price elasticities of the two functions are identical, as are the wage elasticities. The $x$-augmenting technological shift parameter does not appear in the derived money demand equation as $\lambda_{\mathrm{f}} \rightarrow 0$ :

$$
\begin{aligned}
\log m_{i t}=\log L\left(y_{i t}, R_{t}, w_{i t}, A_{i t}, \theta_{i t}\right) & \approx \beta \log y_{i t}-\gamma \log R_{t}+\pi_{\phi}\left(\Psi_{\phi}-\gamma\right) \log \frac{w_{i t}}{R_{t}} \\
& -(1-\gamma) \log A_{i t}+(\text { constant })
\end{aligned}
$$

With the functional forms (1) and (2), it is also true that, as money's share of cost becomes

${ }^{6}$ The expansion path is not log-linear in w/R; the constant $\pi_{\phi}$ in equation (4)' is derived from a log linear approximation to this term. $\pi_{\phi}$ is labor's share of the cost of producing transactions services at some benchmark $w / R$. 
small, the elasticity of money demand with respect to $A$ is $\gamma-1$. (3)' is the primary empirical specification, with the most attention devoted to estimates of $\beta$. For $\beta<1$, I say that there are scal eeconomies in the demand for money by firms. $\beta<1$ means that firms with lots of sales hold proportionally less money than do firms with fewer sales.

\section{II.D Scale Economies and Secular Trends in Velocity}

A more detailed discussion of aggregate data appears in Section VI, but I point out in the present section that the production functions (1) and (2) are consistent with both scale economies in the demand for money $(\beta<1)$ and secular declines in the velocity of circulation. To see this consider the special case of $\psi_{\phi}=1$. In this case, the production of transactions services is Cobb-Douglas:

$$
T_{i t}=A_{i t} m_{i t}^{1-\lambda_{\phi}} l_{i t}^{\lambda_{\phi}}
$$

Assume $\beta<1$. Because of the scale economies, transactions services grow more slowly than do sales or $\mathrm{x}$. Money can grow more rapidly than transactions, however, if wages are growing. Consider the derived demand for money (3)" for the Cobb-Douglas case:

$$
\begin{aligned}
\log m_{i t}=\log L\left(y_{i t}, R_{t}, w_{i t}, A_{i t}, \theta_{i t}\right) & \approx \beta \log y_{i t}-\gamma \log R_{t}+\lambda_{\phi}(1-\gamma) \log \frac{w_{i t}}{R_{t}} \\
& -(1-\gamma) \log A_{i t}+(\text { constant })
\end{aligned}
$$

If sales and wages are growing at the rate $g$ while $R, q$, and $A$ are not growing, then the growth rate of real balances is $\left[\beta+\lambda_{\phi}(1-\gamma)\right]$. For the parameter values $\beta=0.75, \lambda_{\phi}=0.75$, and $\gamma=0.33$, there are economies of scale while real money balances grow $25 \%$ faster than sales and wages. ${ }^{7}$

\section{II.E Identification}

${ }^{7} \lambda_{\phi}$ is the share of labor and $1-\lambda_{\phi}$ the share of money in the cost of producing of transactions services. For the 1993 U.S. economy, R*M1 is about $1 \%$ of GNP. $\lambda_{\phi}=0.75 \mathrm{implies}$ that $3 \%$ of GNP is paid to workers who produce transactions services. 3\% may or may not be accurate for the U.S. economy, but its plausibility shows that the parameters used in the illustrative example above are believable. 
I think of data from firms as approximating the limiting case $\lambda_{f} \rightarrow 0$ and justify this assertion on the grounds that the cost of producing transactions services is fairly small roughly 1-5\% of GNP and an even smaller percentage of aggregate sales. As $\lambda_{f} \rightarrow 0$, the demand for money conditional on $(y, w, R, t)$ is independent of $\theta$.

The determinants of differences in firm size, such as physical differences in the production process (modeled here as the parameter $\theta$ ), are assumed to be independent of intraindustry differences in the level of financial sophistication. Under this assumption, consistent estimates of $\beta$ can be obtained by regressing log money on log sales and log wage in an intraindustry cross-section of firms. $\log A$ is an omitted variable in this regression but, according to the model, is uncorrelated (in a cross-section) with the volume of sales. Notice that the reverse regression does not deliver consistent estimates of $1 / \beta$ because the demand for money is correlated with $A$, the level of financial technology. ${ }^{8}$

A restriction that has been implicitly imposed by equations such as (3)' is that, at a point in time, all firms have the same opportunity cost of holding money. In fact, a less stringent assumption is required for the following empirical analysis - that variations in the opportunity cost are uncorrelated with sales and wages within a two-digit industry at a point in time Variations over time and across industries in the opportunity cost are captured in the empirical analysis by including time effects or time varying industry effects.

Some previous studies of the demand for money by firms, such as Maddala and Vogel (1965) and Vogel and Maddala (1967), have worried that estimates of the sales elasticity are biased in a quantitatively important way by the omission of firm-specific measures of the opportunity cost of holding money. However, there are two reasons why cross-firm differences in the opportunity cost of holding money can be safely ignored in the present study. First, as is shown in section IV, variations in sales across firms - even within a two digit industry - are large enough that an implausibly large covariance between sales and the opportunity cost is required to generate an economically significant bias of estimates of the sales elasticity. To see this, consider a worst-case example. Suppose that $\log y$ and $\log R$ are perfectly correlated and that the interest elasticity is 0.5 ( 0.5 is fairly elastic when compared to time series estimates

${ }^{8} \mathrm{C}$ onsider another model of firm behavior. As before, firms face production functions like equations (1) and (2), but $x$ is exogenously fixed (in a way that is uncorrelated with the level of financial technology). Profit maximizing firms demand money according to (3)'. Like the costminimizing model in the text, sales is uncorrelated with the money demand error term. 
such as Lucas (1988)). Suppose further that the coefficient of variation of the opportunity cost is 0.5. Such a coefficient of variation would arise, for example, if the standard deviation of $R$ were 2.5 annual percentage points and the mean were 5 percentage points per annum. ${ }^{9}$ Since the coefficient of variation of sales of firms, even within a two-digit industry at a point in time, is at least 2, estimated sales elasticities are biased by the amount 0.125 in this extreme case example. A more realistic upper bound on the bias is 0.05 , which takes into account the fact that $\log y$ and $\log R$ fail to be perfectly correlated.

A second reason one can ignore cross-firm differences in $\mathrm{R}$ is that omission of firmspecific measures of In R probably bias estimates of the sales elasticity upward, making it more difficult for the present study to find evidence of economies of scale. The omitted variable bias is upward in the commonly supposed case that large firms, because they may enjoy better access to capital markets, face lower rates of return at the margin.

It has also been assumed that higher wages are not associated with greater productivity in the provision of transactions services. The acceptability of this assumption depends on the source of wage and productivity variations in the data. If wages are high because of a general increase in capital per worker and the production of transactions services are labor intensive relative to other sectors of the economy then we can expect higher wages to increase the demand for money as in equation (3)".

${ }^{9} \mathrm{Firms}$ in this study have filed with the Securities and Exchange Commission. One might therefore expect these firms to enjoy relative easy access to national financial markets. Access to financial markets should limit the scope for differences in rates of return across firms. 


\section{Firm-Level Data}

The firm-level data in this study were obtained from the COMPUSTAT Industrial Annual Expanded (CST-IAX) files. Subsection A provides an overview of the CST-IAX firms. The two definitions of money available in the data set are described in subsection $B$. A final subsection presents the criteria for inclusion of a firm in the money demand estimation.

\section{III.A COMPUSTAT Overview}

15,263 companies are included in the COMPUSTAT data set. Among these are all NYSE and AMEX listed companies. Also included are 10,000 or more U.S. firms who file, or have filed, $10-\mathrm{K}$ forms with the SEC. ${ }^{10}$

The companies report detailed income and balance sheet information on an annual basis for some or all of the years 1950-93. In addition to the monetary information, I am interested in each firm's net income, sales, assets, and number of employees. The data set also includes an industry code (SIC) for each firm and a code (FIPS) for the county of its headquarters.

Sales is defined as "gross sales net of discounts, returns and all owances" (COMPUSTAT, pp. 133-35).

\section{III.B Definitions of Money}

Firms report two items in the asset column that one might associate with money. The first is "cash", defined as "any immediately negotiable medium of exchange. It includes money and any instrument normally accepted by banks for deposit and immediate credit to a customer's account." (COMPUSTAT, Section 9, p. 33) Cash includes bank drafts, banker's acceptances, currency, CD's induded in cash by the company, checks, demand certificates of deposit, demand deposits, letters of credit, and money orders. CD's included as short term investments on the firm's balance sheet, CD's reported as a separate item in current assets, commercial paper, government securities, legally restricted cash, marketable securities, short-term investments, time CD's, and time deposits are not included in the "cash" category.

\footnotetext{
${ }^{10}$ Some Canadian firms are also included in the COMPUSTAT files, but are omitted from this analysis.
} 
I treat "cash" as a good proxy for M1. ${ }^{11}$ The "cash" item is not reported by utilities, life insurance, or property and casualty companies.

A second item is "cash and short-term investments," defined as "cash and all securities readily transferable to cash as listed in the current assets section." "Cash and short-term investments" adds to "cash" accrued interest combined with short term investments, brokerage firms' good faith and clearing house deposits, cash in escrow, cash restricted by federal or other regulations, CD's included as short term investments, CD's reported as a separate item in current assets, commercial paper, gas transfer companies' special deposits, government and other marketable securities, margin deposits on commodity futures, marketable securities, money market funds, repurchase agreements shown as current assets, real estate investment trust shares of beneficial interest, restricted cash, time CD's, time deposits, and treasury bills listed as short term assets. I think of "cash and short-term investments" as a good proxy for L (liquid assets) as defined by the Federal Reserve.

\section{III.C Selection Criteria}

Firm i is included in my data set for year $t$ if two conditions are satisfied. First, "cash" and "sales" must both be reported for that year and not equal to zero. Second, the county of the firm's headquarters must be reported. Most firms are included for only a subset of the years 1956-93. ${ }^{12}$ The right scale of Figure 2 lists the number of included firms by year. The figure shows that, of the total of 12,000 firms that appear in the sample in at least one year, slightly less than half appear in any given year. There are a total of 108,738 firm-years in the main sample. Slightly smaller samples are required to obtain data on sales for two consecutive years. Larger samples are available for a more inclusive measure of money. Section IV.D compares some characteristics of non-cash-reporting firms with those of cash-reporting firms and includes estimates of the sample selection bias.

\section{III.D County Variables}

\footnotetext{
${ }^{11} \mathrm{M} 1$ includes currency, traveler's checks, demand deposits, NOW accounts and super-NOW accounts at commercial banks, share draft accounts at credit unions, automatic transfer savings accounts and other checkable deposits (Goldfeld and Chandler, pp. 506-7). A few items such as bank drafts, banker's acceptances, and letters of credit are not included in M1 but are included in the COMPUSTAT definition of "cash."
}

${ }^{12} \mathrm{No}$ firm satisfies the criteria for any of the years 1950-55. 
In addition to monetary and scale variables, the money demand equation includes three other variables: the nominal interest rate, the price of labor, and the level of financial technol ogy. Time and industry effects are used as proxies for these four variables. In addition, I merge some information on the county where each firm is headquartered. The first variable is the ratio of farm income to total personal income in that county. The second is wage and salary income per empl oyee in the county. Third is the dollar value of unemployment insurance benefits paid to residents of the county. The number of workers who work in each county is the final variable. County data are obtained from the Bureau of Economic Analysis (U.S. Department of Commerce, 1992) for the years 1969-90. The 1969 values of the agricultural, wage and unemployment variables are used for 1956-68 while the 1990 values are used for 1991-93. As Figure 2 shows, it is not crucial that the county variables are lacking for 1956-68 and 1991-93; most firms appear in the sample between 1969 and 1990.

\section{Estimates of the Demand for Currency and Demand Deposits}

\section{IV.A OLS Estimates}

The empirical work focuses on the estimation of the derived demand for money (3)', redisplayed below:

$$
\log m_{i t}=\beta \log y_{i t}-\gamma \log R_{t}+\pi_{\phi}\left(\Psi_{\phi}-\gamma\right) \log \frac{w_{i t}}{R_{t}}-(1-\gamma) \log A_{i t}+\text { (constant) }
$$

I begin with OLS estimates of (3)', using "cash" as the measure of "money." The first column of Table 1 bel ow displays OLS estimates of a regression of log cash on log sales and a set of year dummies. This specification omits any proxies for the level of financial technology, wages, or other prices, but can be taken as a rough estimate of the scale elasticity $\beta$. The estimate of $\beta$, 0.752 , is significantly less than unity. 


\begin{tabular}{|c|c|c|c|c|c|c|c|c|}
\hline \multicolumn{9}{|c|}{ Table 1: Sales and Wage Elasticities of Money Demand (OLS) } \\
\hline \multirow{2}{*}{$\begin{array}{l}\text { independent } \\
\text { variables } \\
\text { log sales }\end{array}$} & \multicolumn{8}{|c|}{ dependent variable: log cash } \\
\hline & $\begin{array}{c}0.752 \\
(0.002)\end{array}$ & $\begin{array}{c}0.744 \\
(0.002)\end{array}$ & $\begin{array}{c}0.751 \\
(0.002)\end{array}$ & $\begin{array}{c}0.744 \\
(0.002)\end{array}$ & $\begin{array}{c}0.739 \\
(0.002)\end{array}$ & $\begin{array}{c}0.830 \\
(0.002)\end{array}$ & $\begin{array}{c}0.763 \\
(0.002)\end{array}$ & $\begin{array}{r}0.373 \\
(0.002)\end{array}$ \\
\hline log wage & & $\begin{array}{c}0.963 \\
(0.030)\end{array}$ & & $\begin{array}{c}0.877 \\
(0.033)\end{array}$ & $\begin{array}{c}0.742 \\
(0.030)\end{array}$ & $\begin{array}{c}0.594 \\
(0.030)\end{array}$ & & \\
\hline $\begin{array}{l}\text { agricultural } \\
\text { area }\end{array}$ & & & $\begin{array}{l}-8.58 \\
(0.47)\end{array}$ & $\begin{array}{l}-2.98 \\
(0.51)\end{array}$ & $\begin{array}{l}-0.49 \\
(0.46)\end{array}$ & $\begin{array}{l}-0.50 \\
(0.44)\end{array}$ & & \\
\hline $\begin{array}{l}\text { agricultural } \\
\text { area }^{2}\end{array}$ & & & $\begin{array}{l}19.75 \\
(1.72)\end{array}$ & $\begin{array}{l}5.60 \\
(1.80)\end{array}$ & $\begin{array}{l}-0.66 \\
(1.67)\end{array}$ & $\begin{array}{c}0.27 \\
(1.58)\end{array}$ & & \\
\hline year effects & yes & yes & yes & yes & yes & yes & yes & yes \\
\hline $\begin{array}{l}\text { year-industry } \\
\text { effects? }\end{array}$ & no & no & no & no & yes & yes & yes & yes \\
\hline firm effects? & no & no & no & no & no & no & yes & $\begin{array}{l}\text { differ- } \\
\text { enced }\end{array}$ \\
\hline$\overline{\mathrm{R}}^{2}$ & 0.59 & 0.60 & 0.59 & 0.60 & 0.69 & 0.70 & 0.83 & 0.03 \\
\hline std error & 1.58 & 1.57 & 1.58 & 1.57 & 1.38 & 1.29 & 0.97 & 1.05 \\
\hline$N$ & 108738 & 108738 & 108738 & 108738 & 108738 & 102088 & 102088 & 87974 \\
\hline \multicolumn{9}{|c|}{$\begin{array}{l}\text { Notes: (1) "cash" is mostly currency and demand deposits. See text for a detailed definition } \\
\text { (2) "agricultural area" is agriculture's share of personal income in the county where the firm is headquartered } \\
\text { (3) "wage" is wages and salaries per employee in the county where the firm is headquartered } \\
\text { (4) year effects are estimated in every regression } \\
\text { (5) N is the number of firm-year cells included in the regression. } N=102088 \text { is the sample used by Mulligan } \\
\text { (1997), which excludes any firm-year with sales less than one million } 1987 \text { dollars and includes only the years } \\
\text { 1961-92. N=87974 is the subsample used by Mulligan (1997) for which lagged cash and sales are observed } \\
\text { (6) standard errors are displayed in parentheses }\end{array}$} \\
\hline
\end{tabular}

Column 2 adds a proxy for the cost of labor: wages and salaries per worker in the county where the firm is headquartered. With the restriction that transactions services complement other inputs $(\gamma<1)$ and that labor is a substitute for money $\left(\psi_{\phi}>1\right)$, the model predicts that wages should increase the demand for money. Column 2 is consistent with this prediction, displaying an estimated wage elasticity of 0.963.

In order for the estimates displayed in column 2 to be consistent, I must assume that price levels, nominal interest rates, and the degree of financial sophistication are uncorrelated across firms with sales and the wage. ${ }^{13}$ One might suppose that price levels and/or the level of financial sophistication are associated with the degree of urbanization of the area where the

\footnotetext{
${ }^{13} Y$ ear effects are estimated in every regression, so I do not need to worry about correlations over time.
} 
firm operates. To the extent that urbanization increases a firm's ability to produce transactions services from a given amount of money and a given quantity of labor, I view the agricultural variable as a proxy for the level of financial technology and expect it to be positively correlated with the demand for money. On the other hand, there may be urban/rural differences in purchasing power parity. To the extent that there are scale economies $(\beta<1)$ and price levels are lower in rural areas, I expect agriculture to be negatively correlated with the demand for money.

Columns 3 and 4 display results from a regression of log cash on log sales, log wage, farming's share of income and its square. Firms headquartered in more agricultural counties demand less money. ${ }^{14}$ The estimated sales elasticity is not much different from the previous specifications; column 4's estimate is 0.744 . Inclusion of the farming variable affects the estimate of the wage elasticity - it fell from 0.963 to 0.877.

It is reasonable to expect that production functions vary across industries, although it is not clear how cross-industry differences in the degree of financial sophistication might be correlated with sales. To check for the possibility that the finding of scale economies in columns 1-4 may be due to cross-industry differences in the degree of financial sophistication, columns 5-8 estimate separate year effects for every industry (equival ently, separate industry effects for every year). ${ }^{15}$ Inclusion of the year-industry effects does not change the estimated sales elasticity; column 5 displays an estimated sales elasticity of 0.739 , which is significantly different from one. Firms headquartered in rural counties or in counties with low wages demand less money. The estimated wage elasticity when the agricultural variable is included is 0.742 .

Both cash and sales are rounded to the nearest $\$ 1000$ by COMPUSTAT. This rounding could bias estimated sales elasticities for small firms. Column 6 therefore repeats the specification of Column 5, but omits any firm-year with sales less than one million 1987 dollars and includes only the years 1961-92 (this is the sample used by Mulligan 1997). The estimated sales elasticity does increase somewhat when the sample is restricted in this way, because of

\footnotetext{
${ }^{14}$ According to the coefficients on the two agricultural terms, the effect of agriculture on money demand becomes positive for very agricultural areas, but the turning point is at an agricultural/personal income ratio of about 0.2 or more. 0.2 is, for a intents and purposes, beyond the range of the data.

${ }^{15} \mathrm{An}$ industry is defined according to the first two digits of the SIC code. There are a total of 1801 year-industry effects.
} 
the apparently different behavior of the smallest firms. See subsection IV.F for some evidence on how the sales elasticity might vary with the level of sales.

Column 7 displays the firm fixed effects (together with year-industry effects) estimator of 0.763 reported by Mulligan (1997). It is found by first deviating each firm-year's log cash and log sales from the means of those variables for the corresponding cross-section. Firm effects are then estimated in the usual way in the resulting panel data set of deviated log cash and log sales. Since most firms are not in the sample every year, it is sufficient to assume that the mean firm effect is the same for each sampled cross-section in order to show that the fixed effect estimator consistently estimates $\beta$ in the model with firm and year-industry fixed effects. Column 8 estimates $\beta=0.373$ by differencing equation (3)' and then estimating year-industry effects on the resulting panel (using the smaller sample required to observe lagged cash and sales).

The firm fixed effect estimate of 0.763 is somewhat lower than the corresponding estimate with only year-industry effects (column 6) while the differenced estimator of 0.373 is a lot lower, a result which is expected if sales are measured with some error. Measurement error is discussed in more detail in the next subsection, but the results reported in Columns 6 and 7 might be used as proposed by Griliches and Hausman (1986) to compute a fixed effects estimator that is consistent in the presence of classical measurement error. Their estimator depends on the number of periods $T$ an observation is repeated - which varies across firms in my sample - but in this case the Griliches and Hausman (1986) estimator is quite insensitive to $\mathrm{T}$ and is approximately 0.86 .

Figure 2 displays cross-sectional estimates of the sales elasticity from two regression specifications. The first specification corresponds to column 5 of Table 1, regressing log cash on log sales, log wage, agriculture and its square, and two-digit industry dummies in each of 24 cross-sections (1969-92). The estimated sales elasticities are graphed as a solid line. Dotted lines illustrate the corresponding 95\% confidence interval. The second specification, corresponding to column 4 of Table 1, omits the industry dummies. Sales elasticities estimated without industry dummies are displayed as a dashed line (no confidence interval is shown). The bars indicate the number of firms in each cross-section. For both specifications, the sales elasticity is less than 0.9 in every year. The hypothesis of $\beta=1$ can be rejected in any crosssection. 


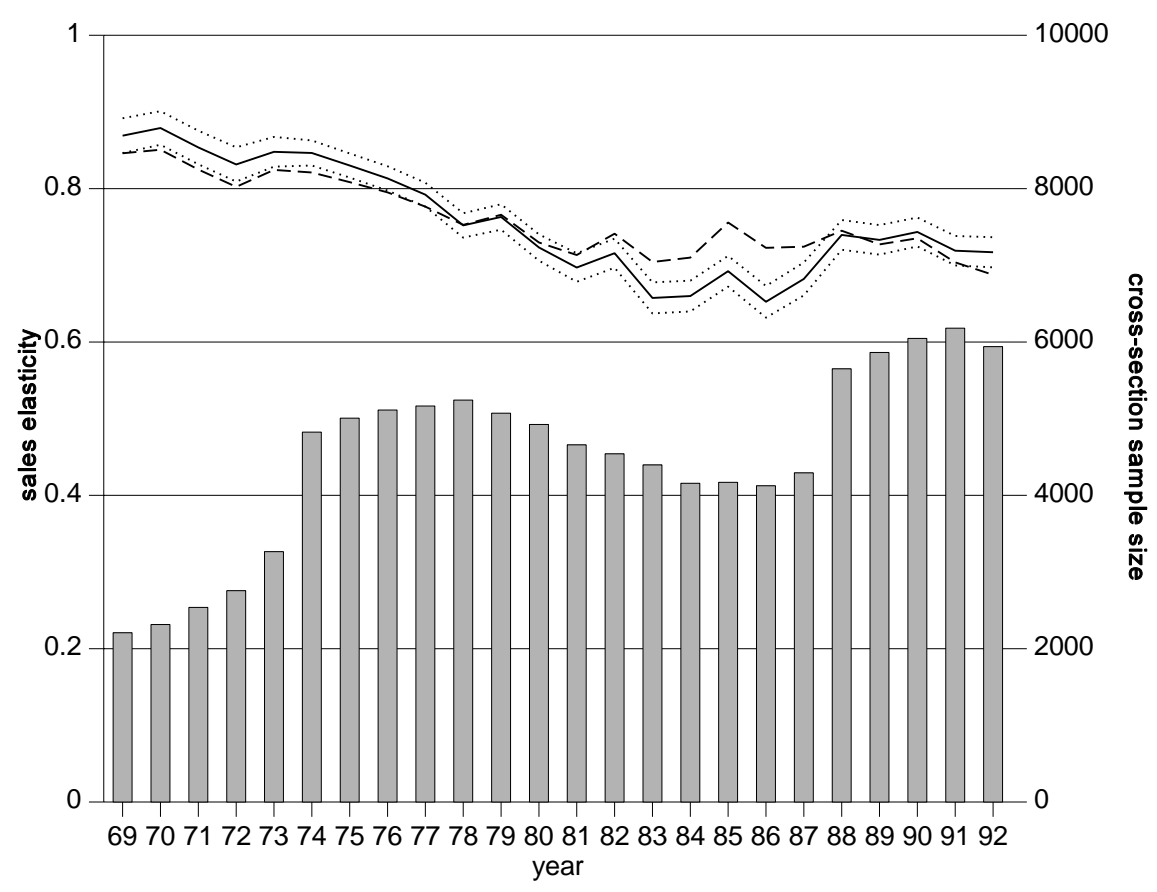

Figure 2 Cross-Sectional Estimates of the Sales Elasticity

I assume that $\beta$ is the same for all industries and all years. Figure 2 suggests that there is some variation over time in $\beta$. $\beta$ may vary across industries although I have found that the Financial, Insurance, and Real Estate (FIRE) industries are the only potential outliers: estimated $\beta$ for FIRE industries is near one is some specifications and near 0.75 for other specifications.

Cross-sectional estimates of the wage elasticity from the same two regression specifications are displayed in figure 3. As in figure 2, the solid line graphs elasticity estimates obtained from cross-sectional regressions with industry dummies; dotted lines illustrating the corresponding 95\% confidence interval. Estimates obtained without industry dummies are displayed, without a confidence interval, as a dashed line. Point estimates from both specifications are positive in every year except 1969. The wage elasticity appears to be increasing over the period, although standard errors are too large to convey very precise information about secular trends. 


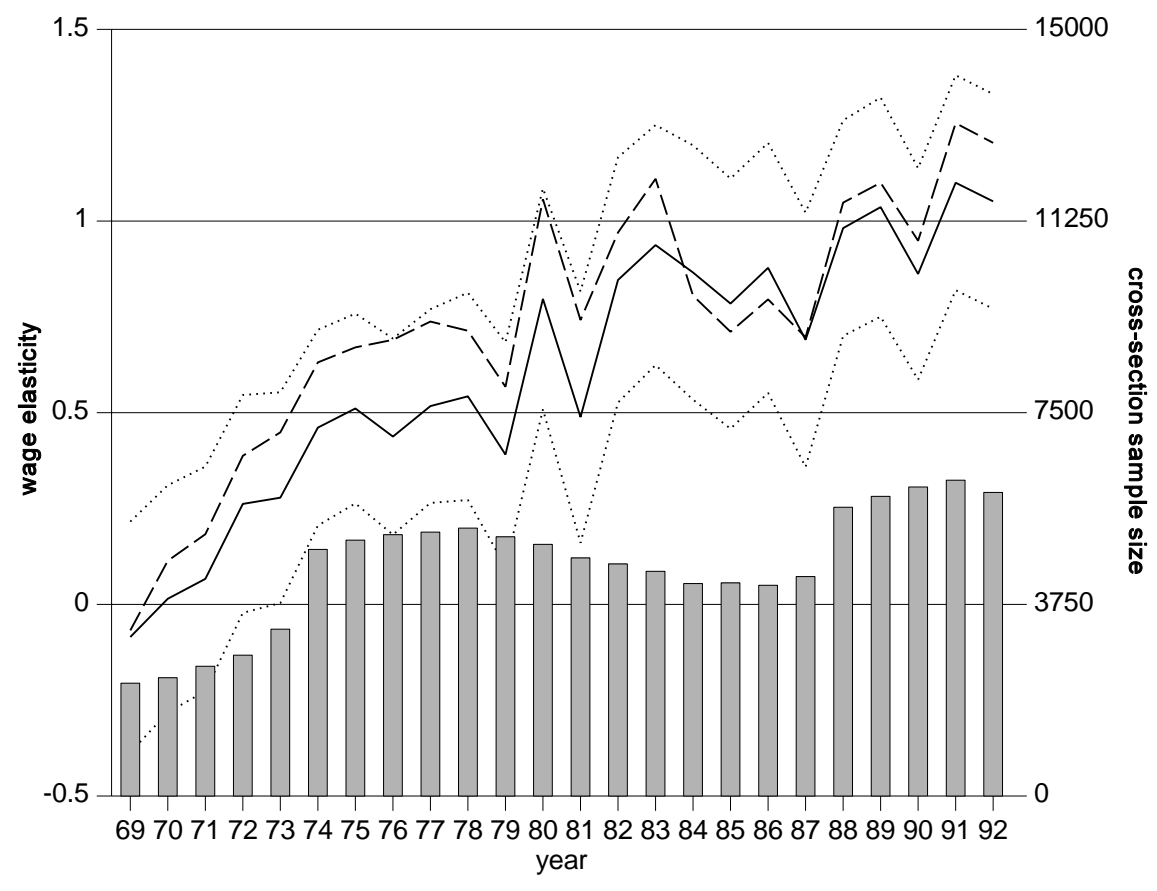

Figure 3 Cross-Sectional Estimates of the Wage Elasticity

Thestandard errors computed for the pool ed estimates displayed in Table 1 assume that all 108,738 error terms are independently distributed. To the extent that any particular firm's error term is serially correlated, the OLS standard errors displayed in Table 1 are understated. ${ }^{16}$ If serial correlation were the only reason the pooled OLS standard errors were misleading, then I can use standard errors computed from the cross-section to put an upper bound on the "true" standard error. As the tight confidence intervals shown in Figure 2 show, the sales elasticity is estimated very precisely in each of the 1969-92 cross-sections; standard errors are close to 0.009 in every cross-section. Thus, with a standard error of the sales elasticity estimate somewhere between 0.002 and 0.009 , I can be confident about the rejection of a unitary sales elasticity.

Confidence about the wage elasticity relies somewhat more on the assumption that multiple cross-sections add independent observations to the analysis. The cross-sectional confidence intervals displayed in Figure 3 are wider (a cross-sectional standard error of 0.15

\footnotetext{
${ }^{16} \mathrm{~N}$ ote, however, that very few firms are in the sample for the entire sample period. E ach year, many firms leave the sample and others join it.
} 
is typical), although one can confidently reject the hypothesis that the wage elasticity is zero. ${ }^{17}$

\section{IV.B Measurement Error}

While the finding of scale economies in the holding of money is not surprising in the light of some theoretical analyses such as Allais (1947), Baumol (1952), Miller \& Orr (1966), and Tobin (1956), one should address the possibility that errors in the measurement of sales are the cause of the rejection of a unitary scale elasticity. If errors in the measurement of sales were of the classical variety, I would expect estimates of the sales elasticity to be biased downward.

One way to address this possibility is to suppose that only sales is measured with error (not money or wages) and run the reverse regression. However, a reverse regression induces an upward bias on the estimated sales elasticity. The bias occurs, according to the theory, because money balances are correlated with the omitted variable $\log A_{i t}$, but sales are not. ${ }^{18}$ Moreover, the reverse regression requires an assumption of a substantial degree of error in the measurement of sales, but not of money. I expect instead that money is (relatively) poorly measured for two reasons. First, cash is a point-in-time report of a stock, as opposed to sales which is time averaged. Second, one can argue that the measured value of sales closely corresponds to its theoretical counterpart, while the measured stock of money may not.

Table 2 tackles the measurement error problem in a different way. Assume that errors in the measurement of sales are serially uncorrelated (and uncorrelated with future shocks to the money demand function). Then consistent estimates of the sales elasticity can be obtained with two stage least squares, using lagged log sales as an instrument for current log sales. ${ }^{19}$

\footnotetext{
${ }^{17}$ The assumption of cross-sectional independence is somewhat less defensible when county variables are included in the regression because some sample firms are in the same county in the same year. Appendix Figure A-1 shows, however, that not too many sample firms are in the same county in the same year. Cross-sectional dependence resulting from the use of county variables affects confidence about the estimates of the coefficients on those variables but, because sales is not highly correlated with the county variables, not confidence about the sales elasticity estimates.

${ }^{18}$ See section II.E for a discussion. The sales elasticities implied by the reverse regressions (not reported in the text) are larger than one and the implied wage elasticities are negative.

${ }^{19}$ If measurement errors are negatively correlated over time (perhaps because sales from year $t$ are misallocated to year $t+1$ or year $t-1$ ), then IV estimates of the sales elasticity are biased upwards.
} 
The first two columns in Table 2 have only log sales and year effects as regressors. Column 1 presents the OLS estimate in the smaller (99549 firm-years) sample required to have information on both current and lagged sales. The IV estimates are presented in column 2; I see only a small change in the estimated sales elasticity. IV estimates are only slightly different when log wage and the agricultural variables are included, as is shown in columns 3 and 4. Adding year-industry effects to the money demand equation, as is done in columns 5-8, fails to contradict the conclusion that IV estimates of the sales elasticity are very close to the OLS ones. One sees, for example, in columns 5 and 6 of Table 2 that the OLS estimate of the sales elasticity is 0.765 when log wage and agriculture are included as regressors, while the corresponding IV estimate is 0.768 .

\begin{tabular}{|c|c|c|c|c|c|c|c|c|}
\hline \multicolumn{9}{|c|}{ Table 2: Sales and Wage Elasticities of Money Demand (OLS \& IV) } \\
\hline \multirow{2}{*}{$\begin{array}{l}\text { independent } \\
\text { variables } \\
\text { log sales }\end{array}$} & \multicolumn{8}{|c|}{ dependent variable: log cash } \\
\hline & $\begin{array}{c}0.775 \\
(0.002)\end{array}$ & $\begin{array}{c}0.778 \\
(0.002)\end{array}$ & $\begin{array}{c}0.767 \\
(0.002)\end{array}$ & $\begin{array}{c}0.769 \\
(0.002)\end{array}$ & $\begin{array}{c}0.765 \\
(0.002)\end{array}$ & $\begin{array}{c}0.768 \\
(0.002)\end{array}$ & $\begin{array}{c}0.834 \\
(0.002)\end{array}$ & $\begin{array}{c}0.830 \\
(0.002)\end{array}$ \\
\hline log wage & & & $\begin{array}{c}0.840 \\
(0.034)\end{array}$ & $\begin{array}{c}0.834 \\
(0.035)\end{array}$ & $\begin{array}{c}0.687 \\
(0.031)\end{array}$ & $\begin{array}{c}0.679 \\
(0.032)\end{array}$ & $\begin{array}{c}0.575 \\
(0.030)\end{array}$ & $\begin{array}{c}0.583 \\
(0.031)\end{array}$ \\
\hline $\begin{array}{l}\text { agricultural } \\
\text { area }\end{array}$ & & & $\begin{array}{l}-3.38 \\
(0.55)\end{array}$ & $\begin{array}{l}-3.39 \\
(0.56)\end{array}$ & $\begin{array}{l}-0.65 \\
(0.49)\end{array}$ & $\begin{array}{l}-0.65 \\
(0.51)\end{array}$ & $\begin{array}{l}-0.65 \\
(0.48)\end{array}$ & $\begin{array}{l}-0.65 \\
(0.49)\end{array}$ \\
\hline $\begin{array}{l}\text { agricultural } \\
\text { area }^{2}\end{array}$ & & & $\begin{array}{c}7.27 \\
(1.99)\end{array}$ & $\begin{array}{c}7.29 \\
(2.04)\end{array}$ & $\begin{array}{l}-0.37 \\
(1.85)\end{array}$ & $\begin{array}{l}-0.35 \\
(1.90)\end{array}$ & $\begin{array}{c}0.45 \\
(1.77)\end{array}$ & $\begin{array}{c}0.43 \\
(1.83)\end{array}$ \\
\hline year effects & yes & yes & yes & yes & yes & yes & yes & yes \\
\hline $\begin{array}{l}\text { year-industry } \\
\text { effects? }\end{array}$ & no & no & no & no & yes & yes & yes & yes \\
\hline$\overline{\mathrm{R}}^{2}$ & .61 & .59 & 61 & .59 & .70 & .68 & .71 & .69 \\
\hline std error & 1.54 & 1.58 & 1.54 & 1.57 & 1.35 & 1.39 & 1.27 & 1.32 \\
\hline $\mathrm{N}$ & 99549 & 99549 & 99549 & 99549 & 99549 & 99549 & 94424 & 94424 \\
\hline OLS or IV? & OLS & IV & OLS & IV & OLS & IV & OLS & IV \\
\hline \multicolumn{9}{|c|}{$\begin{array}{l}\text { Notes: (1) "cash" is mostly currency and demand deposits. See text for a detailed definition } \\
\text { (2) "agricultural area" is agriculture's share of personal income in the county where the firm is headquartered } \\
\text { (3) "wage" is wages and salaries per employee in the county where the firm is headquartered } \\
\text { (4) year effects are estimated in every regression } \\
\text { (5) N is the number of firm-year cells included in the regression. N=94424 is the sample used by Mulligan } \\
\text { (1997), which excludes any firm-year with sales less than one million } 1987 \text { dollars, includes only the years 1961- } \\
92, \text { and includes only firm years for which lagged sales is observed. } \\
\text { (6) For IV estimates, lagged sales is used as an instrument for log sales. agriculture, log wage and dummy } \\
\text { variables are also instruments if they are among the second stage regressors. } \\
\text { (7) standard errors are displayed in parentheses }\end{array}$} \\
\hline
\end{tabular}


As one might expect, an IV procedure leads to higher estimates of the sales elasticity than does OLS, but the magnitude of the difference is (economically) insignificant for all four specifications. The only (minor) exception is shown in columns 7 and 8 for the more restricted sample used by Mulligan (1997).

Another possibility is that, in contrast to the money demand function derived from the model of section II, a firm's demand for money depends on "permanent sales" rather than current sales. If so, then the IV estimates shown in Table 2 are still biased downward. Consider an analogue to Friedman's (1957) permanent income example. Thelog of "permanent sales" $y^{p}$ is updated as an average of current log sales and past permanent log sales:

$$
\log y_{i t}^{p}=\alpha \log y_{i, t-1}^{p}+(1-\alpha) \log y_{i t}
$$

It follows that log permanent sales is a geometrically weighted average of the logs of all past sales. One way to estimate the scale elasticity of money demand, which now depends on permanent sales, is to indude current and all lags of sales in the money demand equations. The sum of coefficients is an estimate of $\beta$. Table 3 includes current and one lag of log sales in the money demand equation. When year-industry effects as well as agriculture, its square, and the log wage are included, the estimated coefficients on current and lagged log sales are 0.701 and 0.065 , respectively. The sum, 0.766 , is reported as the "log run scale elasticity", and is quite similar to the elasticity of 0.765 estimated in column 5 without lagged sales. One might add more lags of log sales to the regression (at the cost of reducing the sample size), but it appears that coefficients on longer lags would be quite small. 
Scale Economies and the Value of Time (12/97) - 21

\begin{tabular}{|c|c|c|c|c|c|c|c|c|}
\hline \multicolumn{9}{|c|}{ Table 3: Permanent Sales Elasticity of Money Demand (OLS) } \\
\hline \multirow{2}{*}{$\begin{array}{l}\text { independent } \\
\text { variables } \\
\text { log sales }\end{array}$} & \multicolumn{8}{|c|}{ dependent variable: log cash } \\
\hline & $\begin{array}{c}0.775 \\
(0.002)\end{array}$ & $\begin{array}{c}0.715 \\
(0.010)\end{array}$ & $\begin{array}{c}0.767 \\
(0.002)\end{array}$ & $\begin{array}{c}0.710 \\
(0.010)\end{array}$ & $\begin{array}{c}0.765 \\
(0.002)\end{array}$ & $\begin{array}{c}0.701 \\
(0.009)\end{array}$ & $\begin{array}{c}0.834 \\
(0.002)\end{array}$ & $\begin{array}{c}0.919 \\
(0.011)\end{array}$ \\
\hline log sales, lag & & $\begin{array}{c}0.061 \\
(0.010)\end{array}$ & & $\begin{array}{c}0.057 \\
(0.010)\end{array}$ & & $\begin{array}{c}0.065 \\
(0.009)\end{array}$ & & $\begin{array}{l}-0.085 \\
(0.011)\end{array}$ \\
\hline $\begin{array}{l}\text { long run scale } \\
\text { elasticity }\end{array}$ & 0.775 & 0.776 & 0.767 & 0.767 & 0.765 & 0.766 & 0.834 & 0.834 \\
\hline log wage & & & $\begin{array}{c}0.840 \\
(0.034)\end{array}$ & $\begin{array}{c}0.837 \\
(0.034)\end{array}$ & $\begin{array}{c}0.687 \\
(0.031)\end{array}$ & $\begin{array}{c}0.684 \\
(0.031)\end{array}$ & $\begin{array}{c}0.575 \\
(0.030)\end{array}$ & $\begin{array}{c}0.577 \\
(0.030)\end{array}$ \\
\hline $\begin{array}{l}\text { agricultural } \\
\text { area }\end{array}$ & & & $\begin{array}{l}-3.38 \\
(0.55)\end{array}$ & $\begin{array}{l}-3.39 \\
(0.55)\end{array}$ & $\begin{array}{l}-0.65 \\
(0.49)\end{array}$ & $\begin{array}{l}-0.64 \\
(0.49)\end{array}$ & $\begin{array}{l}-0.65 \\
(0.48)\end{array}$ & $\begin{array}{l}-0.66 \\
(0.48)\end{array}$ \\
\hline $\begin{array}{l}\text { agricultural } \\
\text { area }^{2}\end{array}$ & & & $\begin{array}{c}7.27 \\
(1.99)\end{array}$ & $\begin{array}{c}7.28 \\
(1.99)\end{array}$ & $\begin{array}{l}-0.37 \\
(1.85)\end{array}$ & $\begin{array}{l}-0.39 \\
(1.85)\end{array}$ & $\begin{array}{c}0.45 \\
(1.77)\end{array}$ & $\begin{array}{c}0.50 \\
(1.77)\end{array}$ \\
\hline year effects & yes & yes & yes & yes & yes & yes & yes & yes \\
\hline $\begin{array}{l}\text { year-industry } \\
\text { effects? }\end{array}$ & no & no & no & no & yes & yes & yes & yes \\
\hline $\mathrm{R}^{2}$ & .61 & .61 & .61 & .61 & .70 & .70 & .71 & .71 \\
\hline std error & 1.54 & 1.54 & 1.54 & 1.54 & 1.35 & 1.34 & 1.27 & 1.27 \\
\hline $\mathrm{N}$ & 99549 & 99549 & 99549 & 99549 & 99549 & 99549 & 94424 & 94424 \\
\hline \multicolumn{9}{|c|}{$\begin{array}{l}\text { Notes: (1) "cash" is mostly currency and demand deposits. See text for a detailed definition } \\
\text { (2) "agricultural area" is agriculture's share of personal income in the county where the firm is headquartered } \\
\text { (3) "wage" is wages and salaries per employee in the county where the firm is headquartered } \\
\text { (4) year effects are estimated in every regression } \\
\text { (5) N is the number of firm-year cells included in the regression. } N=94424 \text { is the sample used by Mulligan } \\
\text { (1997), which excludes any firm-year with sales less than one million } 1987 \text { dollars, includes only the years 1961- } \\
92, \text { and includes only firm years for which lagged sales is observed. } \\
\text { (6) "long run scale elasticity" is the sum of the estimated coefficients on all sales terms } \\
\text { (7) standard errors are displayed in parentheses }\end{array}$} \\
\hline
\end{tabular}

Results from the more restricted sample used by Mulligan (1997) are shown in col umns 7 and 8. Although it is still true that the estimated long run sales elasticity is unaffected by the inclusion of lagged sales, it is interesting to note that lagged sales is negatively related to cash hol dings in this restricted sample. Perhaps this difference is expected because of the extra measurement error for the smallest firms induced by COMPUSTAT rounding. In any case, the negative coefficient on lagged sales is consistent with the predictions of stochastic inventory models such as Miller and Orr (1966). In those models, sales has a dollar-for-dollar effect on cash holdings in the "short run" (and, since sales is larger than cash, a more than proportional effect) where the "short run" is the time period before the "Ss bounds" are hit and a "trip to the 
bank" is triggered. Permanent changes in the amount of sales, on the other hand, change the frequency of "trips to the bank" and therefore have less than a proportional effect on cash holdings. One therefore expects a coefficient on current sales that is larger than the long run el asticity and perhaps even greater than one, depending on how the "short run" compares to the time period over which measured sales are aggregated.

There appears to be little evidence for the hypothesis that estimated sales elasticities are substantially biased as a result of errors in the measurement of sales. This conclusion is not a surprise, as sales is a fairly well defined concept and is easily measured. Cross-sectional differences in measured sales are quite large, both within and across industries. Figure 4 displays a histogram of sales (log scale) for the 108,738 firm-years in the main sample. Some firms have billions of dollars or more in sales (eg., IBM with $\$ 65$ billion in sales in 1992) while others have as few as a hundred thousand dollars. The standard deviation of log sales is 2.5.

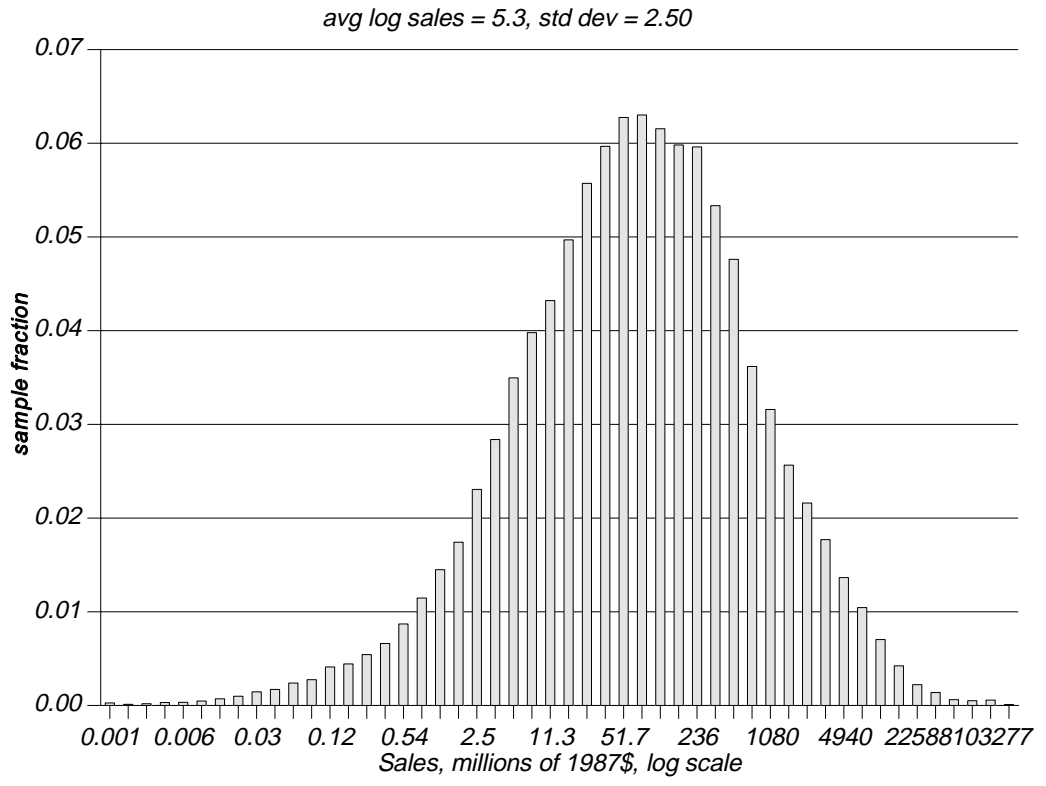

Figure 4 Sample Distribution of Sales $(\mathrm{N}=108,738)$

Because several regressions in this paper include year-industry effects, a measure of the dispersion of sales relevant for interpreting the estimates is the ratio of each firm's sales to the sample average for the corresponding year and industry. Figure 5 looks across industries, displaying a histogram of sales as a ratio to each firm's 2-digit industry average for the year 
(again on a log scale). One sees that, even within industries in a given year, there are vast differences in sales across firms. The standard deviation of the log of the sales to industry average ratio is 2.13. Some firms are a hundred times larger than the industry average, while others are a hundred times smaller.

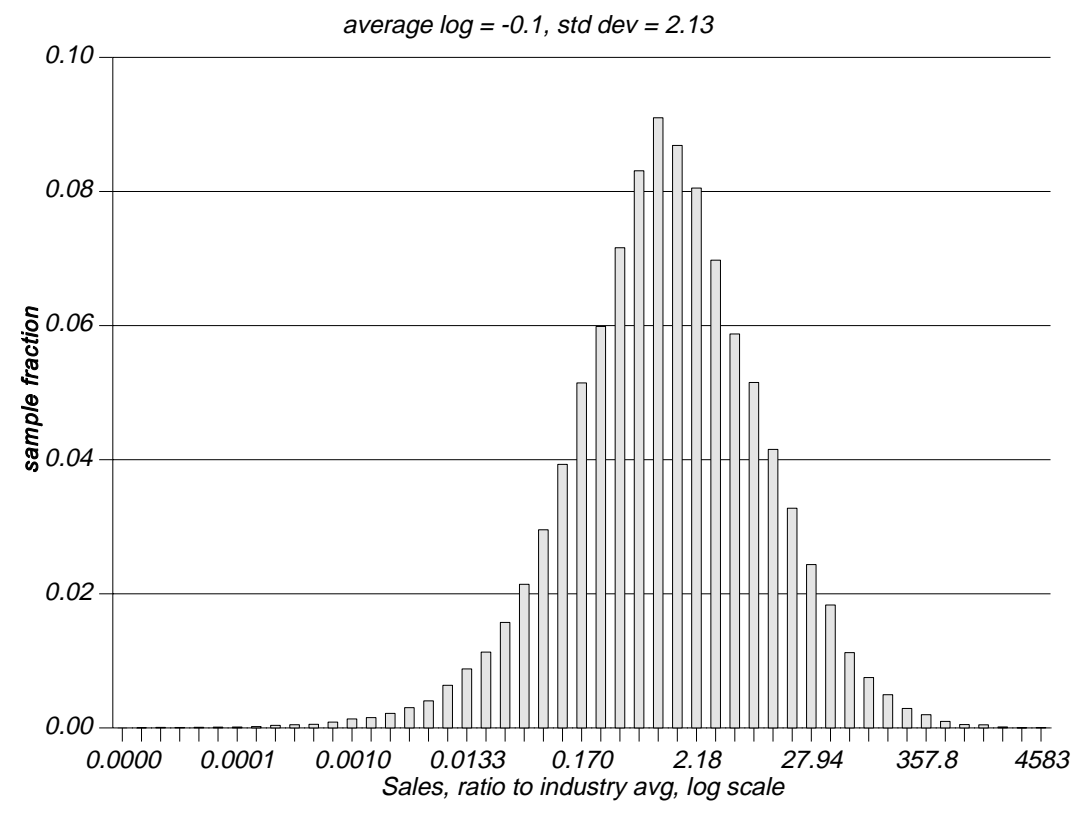

Figure 5 Sample Distribution of (Sales/l ndustry-year Avg) $\mathrm{N}=108,738$

\section{IV.C Business Cycle Effects}

I have interpreted the positive estimated wage elasticity as evidence that time is a substitute for money in the production of transactions services, an interpretation which is crucial if one is concerned with the macro implications of these firm-level money demand functions (see section VI for a discussion). An alternative view of the wage correlation is that both wages and the demand for money vary over the business cycle, but that an exogenous change in the wage would have no effect on the demand for money. Thus, according to the business cycle story, a recession in a region or industry decreases the demand for money at the same time that it decreases wages.

This section presents evidence that a business cycle story cannot explain the positive correlation of "shocks" to the demand for money with a proxy for the wage rate. First, I show that differences in wages across firms (more accurately, differences in the average annual 
earnings in the county where firms are headquartered) are very persistent. ${ }^{20}$ Second, a proxy for the unemployment rate in the county where the firm is headquartered is introduced into the money demand equation together with the average earnings of that county. There is some evidence that firms demand more money for a given level of sales in good economic times, but estimates of the wage elasticity do not change when the unemployment variables are introduced. Third, estimated wage elasticities are still as large as 0.74 when industry-based, as opposed to geography-based, proxies for the business cycle are introduced into the money demand equation.

Different counties are at different stages of the business cycle, but this is not the primary reason why there are cross-county differences in wages. For example, the cross-county correlation of the log of wages and salaries per worker for 1990 and the same variable for 1970 is 0.68 ; wages regress to the mean at about $2 \%$ per year across counties. The fact that crosscounty differences in wages are persistent call into question the business cycle interpretation of the estimated wage elasticity.

As a proxy for the business cycle conditions facing each firm, this study uses annual county-level data on unemployment insurance payments for the years 1969-90. I argue that the ratio of unemployment insurance benefits per employee in a county in a particular year, relative to the county's average for the years 1969-90, is a good proxy for that county's position in the business cycle. The ratio is deviated from the county average to allow for location specific unemployment insurance policies or sectoral composition that might independently influence the quantity of unemployment insurance payments. The ratio is correlated with a more commonly employed business cycle variable, the unemployment rate. To see this, the time series of cross-county averages of the u.i.-employment ratio displayed as the solid line in Figure 6. The figure shows that the ratio moves with the U.S. unemployment rate for all workers (displayed in the figure as a dashed line) over time.

${ }^{20}$ Some of the persistence wage differences, however, are associated with Census region. Firms headquartered in low wage Census regions actually hold more money. Thus the wage elasticities reported in this paper are due to within-Census-region wage differences; the estimated wage elasticity increases by about 0.1 when Census region dummies are included in the $\log ($ cash) regressions. 


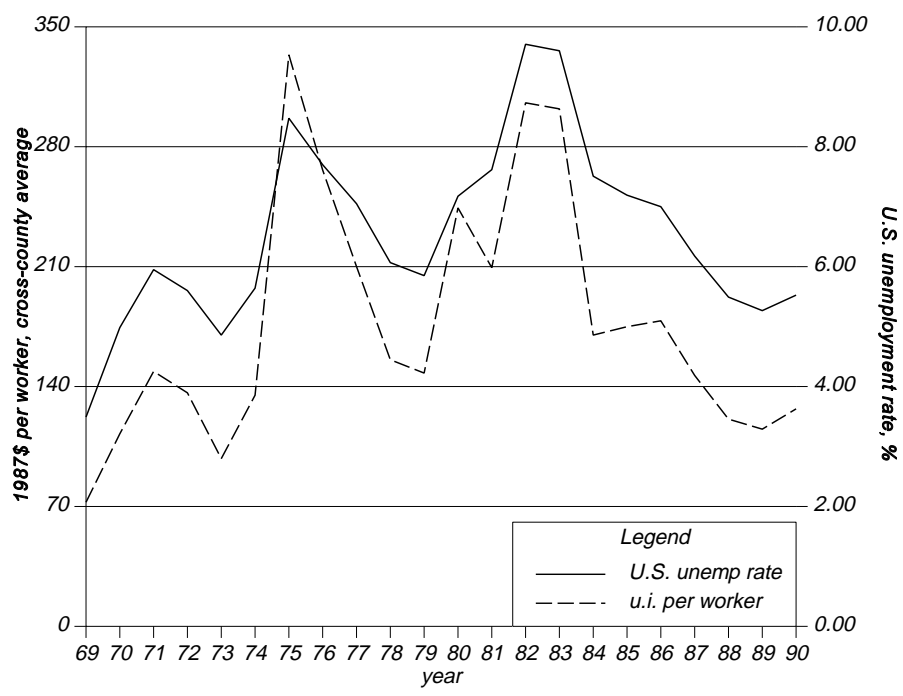

Figure 6 Unemployment insurance benefits per worker as a business cycle variable

Per worker unemployment insurance benefits are also a reasonable cross-sectional business cycle measure. In a cross-section of 3083 counties for the year 1990, the unemployment rate and u.i. benefits per worker have a correlation of $0.49 .^{21}$

Table 4 introduces the u.i. per worker variable (deviated from the county average) into the money demand equation. One sees that estimates of the sales and wage elasticities of money demand are insensitive to the inclusion of this business cycle variable.

${ }^{21}$ The civilian unemployment rate for 1990 is computed at the county level by the Missouri State Census Data Center using the 1990 Census of Population and can be obtained over the internet at bigcat.missouri.edu. 


\begin{tabular}{|c|c|c|c|c|c|c|c|c|}
\hline \multicolumn{9}{|c|}{ Table 4: Business Cycle Effects (OLS) } \\
\hline \multirow{2}{*}{$\begin{array}{l}\text { independent } \\
\text { variables } \\
\text { log sales }\end{array}$} & \multicolumn{8}{|c|}{ dependent variable: log cash } \\
\hline & $\begin{array}{c}0.744 \\
(0.002)\end{array}$ & $\begin{array}{c}0.744 \\
(0.002)\end{array}$ & $\begin{array}{c}0.744 \\
(0.002)\end{array}$ & $\begin{array}{c}0.745 \\
(0.002)\end{array}$ & $\begin{array}{c}0.739 \\
(0.002)\end{array}$ & $\begin{array}{c}0.739 \\
(0.002)\end{array}$ & $\begin{array}{c}0.739 \\
(0.002)\end{array}$ & $\begin{array}{c}0.739 \\
(0.002)\end{array}$ \\
\hline log wage & $\begin{array}{c}0.963 \\
(0.030)\end{array}$ & $\begin{array}{l}0.958 \\
(0.030)\end{array}$ & $\begin{array}{c}0.877 \\
(0.033)\end{array}$ & $\begin{array}{c}0.872 \\
(0.033)\end{array}$ & $\begin{array}{c}0.759 \\
(0.028)\end{array}$ & $\begin{array}{c}0.759 \\
(0.028)\end{array}$ & $\begin{array}{c}0.742 \\
(0.030)\end{array}$ & $\begin{array}{c}0.743 \\
(0.030)\end{array}$ \\
\hline $\begin{array}{l}\text { agricultural } \\
\text { area }\end{array}$ & & & $\begin{array}{l}-2.98 \\
(0.51)\end{array}$ & $\begin{array}{l}-3.01 \\
(0.51)\end{array}$ & & & $\begin{array}{l}-0.49 \\
(0.46)\end{array}$ & $\begin{array}{l}-0.50 \\
(0.46)\end{array}$ \\
\hline $\begin{array}{l}\text { agricultural } \\
\text { area }^{2}\end{array}$ & & & $\begin{array}{l}5.60 \\
(1.80)\end{array}$ & $\begin{array}{c}5.61 \\
(1.80)\end{array}$ & & & $\begin{array}{l}-0.66 \\
(1.67)\end{array}$ & $\begin{array}{l}-0.64 \\
(1.67)\end{array}$ \\
\hline temporary u.i. & & $\begin{array}{c}5.47 \\
(7.76)\end{array}$ & & $\begin{array}{c}4.13 \\
(7.76)\end{array}$ & & $\begin{array}{l}-7.09 \\
(7.08)\end{array}$ & & $\begin{array}{l}-7.45 \\
(7.08)\end{array}$ \\
\hline temporary u.i. ${ }^{2}$ & & $\begin{array}{l}-7700 \\
(1638)\end{array}$ & & $\begin{array}{l}-7691 \\
(1638)\end{array}$ & & $\begin{array}{c}-98 \\
(1474)\end{array}$ & & $\begin{array}{c}-107 \\
(1474)\end{array}$ \\
\hline year effects & yes & yes & yes & yes & yes & yes & yes & yes \\
\hline $\begin{array}{l}\text { year-industry } \\
\text { effects? }\end{array}$ & no & no & no & no & yes & yes & yes & yes \\
\hline $\mathrm{R}^{2}$ & .60 & .60 & .60 & .60 & .69 & .69 & .69 & .69 \\
\hline std error & 1.57 & 1.57 & 1.57 & 1.57 & 1.38 & 1.38 & 1.38 & 1.38 \\
\hline $\mathrm{N}$ & 108738 & 108738 & 108738 & 108738 & 108738 & 108738 & 108738 & 108738 \\
\hline \multicolumn{9}{|c|}{$\begin{array}{l}\text { Notes: (1) "cash" is mostly currency and demand deposits. See text for a detailed definition } \\
\text { (2) "agricultural area" is agriculture's share of personal income in the county where the firm is headquartered } \\
\text { (3) "wage" is wages and salaries per employee in the county where the firm is headquartered } \\
\text { (4) "temporary u.i" is unemployment insurance benefits per worker in the county where the firm is } \\
\text { headquartered minus that county's average u.i. for the years 1969-90 } \\
\text { (5) year effects are estimated in every regression } \\
\text { (6) N is the number of firm-year cells included in the regression } \\
\text { (7) standard errors are displayed in parentheses }\end{array}$} \\
\hline
\end{tabular}

An alternative business cycle variable is unemployment benefits per worker, as opposed to unemployment benefits per worker deviated from the 1960-90 county average. It is less appealing to call the former variable a business cycle variable as there are very persistent differences in this ratio across counties. ${ }^{22}$ However, the ratio fits better in the money demand equation than does the ratio deviated from the 1969-90 mean. Results with the ratio alone are not reported in a table for two reasons. First, introducing the ratio does not affect estimates of the sales and wage elasticities. Second, I see no theoretical justification for preferring a permanent u.i variable over a temporary u.i. variable.

${ }^{22}$ The same criticism applies to the unemployment rate. 
I have estimated the wage elasticity using differences in the location of firms. Moreover, Tables 1 and 4 show that the estimates are sensitive to inclusion of time-varying industry effects. I have interpreted the industry effects as proxies for industry specific differences in the production function, but one might also argue that, at a point in time, different industries are at different stages of the business cycle and that a business cycle variable needs to be included in the money demand equation. To the extent business cycle effects are common within an industry, estimates of the wage elasticity do not reflect business cycle effects whenever time varying industry effects are estimated, such as in columns 5 - 8 of Table 1.

\section{IV.D Selection Bias}

The set of firms which appear in my samples for estimation of the sales elasticity are a subset of all U.S. firms. ${ }^{23}$ This section suggests how my estimates of the demand for money might be indicative of the demand for money by a typical U.S. firms. On one potential source of selection bias - the decision by COMPUSTAT firms to report money as a separate balance sheet item - I have some significant evidence. There is also information on a second source the selection of firms into the COMPUSTAT data set.

A substantial fraction of the COMPUSTAT firms that report their sales do not report their cash holdings. F or example, there are 152,550 firm-years that, if they had reported their cash holdings, would be eligible for inclusion in Tables 1 and 4 . However, only 108,738 of those firm-years (71\%) actually do report cash. To consider the selection bias that arises from omitting the 36,889 non-cash-reporting firms from the regressions, I first compare the typical reporting firm-year to the typical nonreporting firm-year.

${ }^{23}$ The COMPUSTAT firms in my sample account for $30-50 \%$ of the sales reported by corporations to the IRS (see Appendix Table A-1 and IRS, various issues). For example, \$2.6 trillion in sales appear in my sample for 1987 compared to the $\$ 8.4$ trillion in "business receipts" reported by U.S. corporations to the IRS (IRS, 1987 Table 2). 


\begin{tabular}{|c|c|c|}
\hline \multicolumn{3}{|c|}{ Table 5: Cash-reporting vs. Non-cash-reporting firms (all years pooled) } \\
\hline & Cash-reporting & Non-cash-reporting \\
\hline $\mathrm{N}$ & 108,738 & 43,812 \\
\hline average sales & 668 & 858 \\
\hline average log sales & 3.95 & 4.80 \\
\hline average wage & 23,283 & 26,155 \\
\hline average log wage & 10.04 & 10.11 \\
\hline \multicolumn{3}{|c|}{$\begin{array}{l}\text { Note (1) sales is in millions of } 1987 \$ \text {. } \\
\text { ( } 2 \text { ) "wage" is average annual earnings per worker in the county where the firm is } \\
\text { headquartered and is measured in } 1987 \$ \text {. } \\
\text { (3) the GNP implicit price deflator is used to convert all current } \$ \text { to } 1987 \$ \text {. }\end{array}$} \\
\hline
\end{tabular}

We see in Table 5 that the average nonreporting firm has more sales (and slightly higher wages) than the average nonreporting firm. On a year-by-year basis, the average nonreporting firm is larger than the average reporting firm in 24 of 24 cross-sections (1969-92).

Since the decision to report cash does not appear to be random, more needs to be said about each firm's probability of inclusion in the sample. A plausible explanation for a firm's neglecting to report cash is that cash is "too small." For example, a firm with little cash may not choose to separate it from other current assets in its annual report or may not find doing so worth the cost of counting. Or the value for cash holdings may be truncated in the process of coding by COMPUSTAT. How sample selection biases OLS estimates of the sales elasticity depends on the magnitude of the relationship between sales and the selection rule. Since it appears from Table 5 that the typical nonreporting firm has more sales, the "too small" hypothesis predicts that the true sales elasticity is smaller than those reported in Tables 1-4. The rejection of the unitary sales elasticity inferred from the OLS results cannot, according to the "too small" selection hypothesis, be attributed to this form of sample selection bias. ${ }^{24}$

To obtain a rough estimate of the magnitude of the upward sample selection bias, I estimate the model (5):

${ }^{24} \mathrm{E}$ stimates of a probit model are consistent with the inferences that I have drawn from Table 5: log sales has a negative effect on the probability of reporting cash in a probit model with year dummies, log sales, log wage, agriculture and its square as explanatory variables. Log wage has a statistically insignificant effect on the reporting probability, with a point estimate that is roughly one-eighth of the coefficient on log sales. 


$$
\begin{aligned}
& \log m_{i t}=\beta_{t} \log y_{i t}+\pi_{\phi, t}\left(\Psi_{\phi, t}-\gamma_{t}\right) \log w_{i t}+\delta_{t}^{\prime} Z_{i t}+\varepsilon_{i t} \\
& m_{i t} \text { observed if } \log m_{i t}>\log \underline{m_{i t}} \equiv \rho_{y, t} \log y_{i t}+\rho_{w, t} \log w_{i t}+\rho_{Z, t}^{\prime} Z_{i t}+\eta_{i t} \\
&\left(\begin{array}{c}
\varepsilon_{i t} \\
\eta_{i t}
\end{array}\right) \sim N\left(0, \Sigma_{t}\right)
\end{aligned}
$$

where $Z_{\mathrm{t}}$ 's are vectors comprised of a constant term, year t's agriculture, and the square of agriculture. ${ }^{25}$ The random censorship point $\log \underline{m}_{\mathrm{t}}$ and the error terms are unobserved. $\rho_{\mathrm{y}}$ greater (less) than zero all ows for the possibility that large (small) firms are less likely to report a given amount of money. For given wage and $Z$ variables, the sign of the selection bias depends on whether $\rho_{y}$ is greater or less than the sales elasticity of money demand (and this is true regardless of the form of the error distribution). Thus, if this form of selection bias is to explain the deviation of my OLS estimates from unity, it is necessary that $\rho_{y}<\beta$. However, $\rho_{y}$ $<\beta$ is inconsistent with Table 5 which shows that non-reporting firms are larger.

When the model (5) is estimated by maximizing the likelihood function separately for cross-sections at 5-year intervals 1970-90, the estimated sales and wage elasticities are quite similar to their OLS counterparts. ${ }^{26}$ The selection corrections for the sales and wage elasticities (defined to be the difference between estimates of the model (5) and the corresponding OLS estimates displayed in Figures 2 and 3) are displayed for each of the 24 cross-sections in Figure 7. The selection corrections are all economically insignificant. Estimates of the selectivity bias of the sales elasticity are always negative, while corrections of the wage elasticity are either positive or negative depending on the year. The negativity of the small sales elasticity selection corrections is consistent with the idea that the censorship point $\log \underline{m}_{i t}$ is slightly more sensitive to sales than is the demand for money.

\footnotetext{
${ }^{25}$ Industry dummies are not included in the model (5) in order to facilitate computation. The sample used is the Mulligan (1997) sample of 102,088 cash reporting and 35,141 cash nonreporting firm-years with sales of at least one million 1987 dollars.

${ }^{26}$ The sales and wage elasticities are identified in the model (5) only because the form of distribution of the error terms is assumed to be known; my primary objectives in estimating the model are to offer an explicit story of the reporting behavior of firms and to provide a rough indication of the magnitude of the upward sample selection bias.
} 


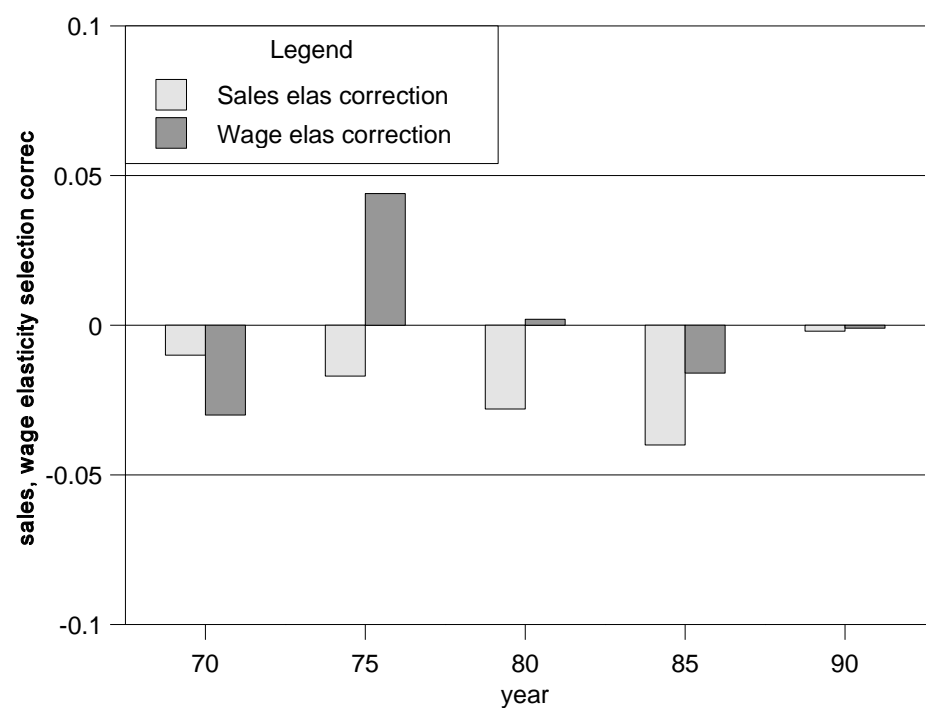

Figure 7 Sales \& Wage Elasticity Selection Corrections

Another way to assess the importance of selection bias is to study quantile regression with samples that assign very small cash values to the nonreporting firms, Table 6 reports cross-sectional estimates of the sales elasticity for the five quantiles $0.1,0.3,0.5,0.7,0.9$ and for the five cross-sections $1970,75,80,85$, and 90 . For comparison, the Table also reports OLS estimates (analogous to those displayed in Figure 2, but using the Mulligan (1997) sample) and the fraction of cash-nonreporting firms for each cross-section. 


\begin{tabular}{|c|c|c|c|c|c|c|c|}
\hline \multicolumn{8}{|c|}{ Table 6: Quantile Regression Estimates of the Sales Elasticity } \\
\hline \multirow{2}{*}{$\begin{array}{l}\text { cross- } \\
\text { section }\end{array}$} & \multicolumn{5}{|c|}{ quantile } & \multirow{2}{*}{$\begin{array}{l}\text { fraction not } \\
\text { reporting cash }\end{array}$} & \multirow{2}{*}{$\begin{array}{l}\text { OLS estimate from } \\
\text { cash-reporting } \\
\text { cross-section }\end{array}$} \\
\hline & 0.1 & 0.3 & 0.5 & 0.7 & 0.9 & & \\
\hline 1970 & & 0.898 & 0.888 & 0.855 & 0.797 & 0.155 & 0.870 \\
\hline 1975 & 0.673 & 0.846 & 0.821 & 0.775 & 0.724 & 0.060 & 0.848 \\
\hline 1980 & & 0.755 & 0.775 & 0.744 & 0.701 & 0.137 & 0.839 \\
\hline 1985 & & & 0.688 & 0.751 & 0.785 & 0.370 & 0.868 \\
\hline 1990 & 0.657 & 0.834 & 0.810 & 0.790 & 0.776 & 0.056 & 0.835 \\
\hline \multicolumn{8}{|c|}{$\begin{array}{l}\text { Notes: (1) firms that do not report cash are assigned log(cash) }=-20 \\
\text { (2) Sample is that used by Mulligan (1997), which excludes any firm-year with sales less than one million } 1987 \\
\text { dollars. } \\
\text { (3) log(wage) is also included in each quantile regression }\end{array}$} \\
\hline
\end{tabular}

Consider, for example, the 1980 cross-section where $13.7 \%$ of firms (that satisfy the other selection criteria) do not report cash. These $13.7 \%$ are arbitrarily assigned small values for cash, so that the 0.1 quantile regression estimate does not make much sense, However, the 0.3, 0.5, 0.7, and 0.9 quantiles are not affected by the assignment. We see, for example, that 1980 median regression estimate of the sales elasticity is 0.775 , which is somewhat smaller than the OLS estimate of 0.839 from the cash-reporting sample. As argued above, we expect the quantile regression estimates to suggest that the selection bias is positive - most of the quantile regression estimates are in fact smaller than the OLS estimate for the corresponding cashreporting cross-section.

COMPUSTAT does not include all U.S. firms. Whether or not my estimates of the sales elasticity are indicative of the typical U.S. firm depends on the relationship between money holdings, firm size, and inclusion in the COMPUSTAT data set. If inclusion is correlated with sales but, conditional on sales and the other explanatory variables, uncorrelated with money holdings, then my OLS estimates are free from selection bias. A comparison of IRS statistics with some computed from COMPUSTAT provide some evidence on this point. According to the IRS, the typical U.S. corporation held about $\$ 0.10$ of cash per dollar of annual sales, as compared to $\$ 0.05$ or $\$ 0.10$ for the COM PUSTAT firms in my main sample. Although the data are rough, they - together with a null hypothesis of a unitary sales elasticity - indicate that COMPUSTAT firms have smaller (more negative) money demand error terms than average. 
To the extent that COMPUSTAT firms are larger than average, the exclusion of nonCOMPUSTAT firms from my sample probably leads to an upward bias of the sales elasticity. ${ }^{27}$

\section{IV.E Firm-specific deflators}

"Real" money balances - as opposed to nominal money balances - enter a firm's production function. My interpretation of the specifications above assume that the appropriate deflator for nominal money balances is common across firms, or at least uncorrelated with sales and wages within a two-digit industry at a point in time once time the agricultural variables are held constant. This subsection considers the quantitative importance of this assumption.

Assume that the production function (1) is still valid, but that $y_{i t}$ denotes output. Let $s_{i t} \equiv p_{i t} y_{i t}$ denote sales. $p_{i t}$ is the date $t$ average sales price of a unit of firm i's output. ${ }^{28}$ Let $M_{i t}$ denote firm i's nominal money balances at date $t$ and define real money balances $m_{i t}$ to be $M_{i t} / P_{i t}$, where $P_{i t}$ is the geometric average of input prices $\left(q_{i t}\right)$ and output prices $\left(p_{i t}\right)$ :

$$
P_{i t} \equiv \sqrt{\bar{q}_{i t} p_{i t}}
$$

According to the production functions (1) and (2), there are two nonmonetary inputs: $x$ and labor. Let $\mathrm{q}_{\mathrm{it}}$ be the price of the nonlabor components of $\mathrm{x}$. If we suppose that the input price index $q_{i t}$ can be approximated as a weighted geometric mean of $q_{t}$ and $w_{i t}$, then (3)' implies the expression (3)"' for firm i's demand for nominal money balances at date t:

$$
\begin{aligned}
\log M_{i t} & =\beta \log s_{i t}-\left[\gamma+\pi_{\phi}\left(\Psi_{\phi}-\gamma\right)\right] \log R_{t}-(1-\gamma) \log A_{i t}+\left[\frac{1}{2}-\beta\right] \log p_{i t}+(\text { constant }) \\
& +\left[\pi_{\phi}\left(\Psi_{\phi}-\gamma\right)+\alpha\left[\frac{1}{2}+\gamma-\pi_{\phi}\left(\Psi_{\phi}-\gamma\right)\right]\right] \log w_{i t}+(1-\alpha)\left[\frac{1}{2}+\gamma-\pi_{\phi}\left(\Psi_{\phi}-\gamma\right)\right] \log q_{i t}
\end{aligned}
$$

where $\alpha$ is labor's share of the firm's costs (think of labor as both a component of $\mathrm{x}$ and an

\footnotetext{
${ }^{27}$ The average firm in my sample has sales in the hundreds of millions of dollars, compared to the two or three million dollars in business receipts reported to the IRS per corporate income tax return (IRS, various issues).

${ }^{28}$ I nventory accumulation is neglected.
} 
argument of the transactions services production function).

$\log q_{i t}$ and $\log p_{i t}$ are omitted variables in the specifications reported in Tables 1-4. Estimates of $\beta$ are biased only if - within an industry at a point in time - $\log q_{i t}$ and $\log p_{\text {it }}$ are correlated with log sales. It is doubtful, however, that output prices and nonlabor input prices vary much within an industry relative to the massive variation in sales (remember that the standard deviation of log sales net of year-industry effects is larger than 2).

Strictly speaking, the estimated coefficient on log w can no longer be interpreted as an unbiased estimate of the mongrel substitution parameter $\pi_{\phi}\left(\psi_{\phi}-\gamma\right)$. The bias depends on $\alpha\left[\gamma-\pi_{\phi}\left(\Psi_{\phi}-\gamma\right)+1 / 2\right]$. However, data from the national accounts and the IRS Statistics of Income suggest that, in the case $\gamma \leq \pi_{\phi}\left(\psi_{\phi}-\gamma\right)$ this bias can be no larger than 0.19 . Consider the ratio of aggregate employee compensation (from the national accounts) to the aggregate sales of corporations filing returns with the IRS. Because many employees do not work for corporations that file with the IRS, this ratio is clearly an overstatement of labor's share of cost $(\alpha)$. Since the ratio is $0.37,0.38$, and 0.38 in the three years 1960, 1970, and 1980, respectively, the bias $\alpha / 2$ is almost certainly less than 0.19 . The evidence displayed in Tables $1-4$ is therefore consistent with the hypothesis that labor substitutes for money in the provision of transactions services.

\section{IV.F Nonlinear Money Demand}

The functional forms (1) and (2) imply a derived demand for money that is log-linear in sales, but it is conceivable that the sales elasticity might vary with the level of sales. Table 7 reports estimate of equation (3)' using samples of firm-years with fairly similar sales. The table suggests that the sales elasticity does not vary with the level of sales, with perhaps the exception of sales less than $\$ 1$ million or $\$ 10$ million. 


\begin{tabular}{|c|c|c|c|c|}
\hline \multicolumn{5}{|c|}{ Table 7: Sales Elasticity as a Function of Sales } \\
\hline \multicolumn{2}{|c|}{ Sales Sample: } & \multicolumn{3}{|c|}{ Sales Elasticity } \\
\hline \multirow[t]{2}{*}{$\min$} & \multirow[t]{2}{*}{$\max$} & \multirow{2}{*}{$\begin{array}{l}\text { Full } \\
\text { Sample } \\
\text { OLS }\end{array}$} & \multicolumn{2}{|c|}{ IV Sample } \\
\hline & & & OLS & IV \\
\hline 0.001 & 1 & 0.218 & 0.288 & 0.355 \\
\hline 1 & 10 & 0.629 & 0.634 & 0.576 \\
\hline 10 & 100 & 0.856 & 0.856 & 0.820 \\
\hline 100 & 1000 & 0.831 & 0.825 & 0.814 \\
\hline 1000 & & 0.904 & 0.903 & 0.982 \\
\hline \multicolumn{5}{|c|}{$\begin{array}{l}\text { Notes: (1) Sales in millions of current \$ } \\
\text { (2) log(wage) and year-industry effects are include in each regression } \\
\text { (3) "IV sample" excludes firm years for which lagged sales are not observed } \\
\text { (4) IV estimates use lagged log sales, log(wage) and year-industry effects as } \\
\text { instruments for log sales }\end{array}$} \\
\hline
\end{tabular}

\section{IV.G A Comparison with Earlier Studies of Firms}

Three earlier studies - Meltzer (1963a), Maddala and Vogel (1965), and Vogel and Maddala (1967) - used cross-sections of firms to estimate the degree of scale economies in cash holdings, estimating sales elasticities near one. There are four important design differences between these previous studies and mine:

(i) The previous studies used cross-sections of industry/asset class aggregates, as aggregated by the IRS. The industries are mainly manufacturing.

(ii) The previous studies were for a different time period (1950's).

(iii) The previous studies did not use any longitudinal information.

(iv) The previous studies did not have the information necessary to estimate a wage elasticity.

Two questions arise "Why did the previous studies obtain a different estimate of the sales elasticity?" and "What new has been learned from the present study?."

One potential design difference that might generate smaller estimated sales elasticities in my study is the extra measurement error inherent in micro-level data. However, the analysis above suggests that such measurement error biases are quite small. Four remaining 
possibilities are: (1) the previous studies are subject to aggregation bias, (2) scale economies were less important in the earlier period, (3) the industries used by the earlier studies are special, and (4) the sales elasticity varies with the level of sales and large and small firms are weighted differently in the two studies. By combining my COMPUSTAT data with IRS industry aggregate data for a comparable time period, I can assess the importance of each of the four possibilities.

\begin{tabular}{|c|c|}
\hline \multicolumn{2}{|c|}{$\begin{array}{l}\text { Table 8: Reconciliation with Previous Cross-Sectional Studie } \\
\text { of Firms }\end{array}$} \\
\hline Data Set & Sales elas. \\
\hline COMPUSTAT micro data & 0.74 \\
\hline $\begin{array}{l}\text { COMPUSTAT micro data } 1961-92 \text { excluding } \\
\text { firm-years with sales less than one million } \\
1987 \$\end{array}$ & 0.83 \\
\hline $\begin{array}{l}\text { COMPUSTAT micro data 1961-92, excluding } \\
\text { firm-years with sales less than one million } \\
1987 \text { \$, Meltzer industries only }\end{array}$ & 0.81 \\
\hline $\begin{array}{l}\text { COMPUSTAT micro data 1961-92, excluding } \\
\text { firms with sales less than one million } 1987 \text {, } \\
\text { Meltzer industries only, aggregated by } \\
\text { industry \& asset class }\end{array}$ & 0.96 \\
\hline Cross-industry/asset class IRS data, 1963 & 0.99 \\
\hline Cross-industry/asset class IRS data, 1957 & 1.01 \\
\hline \multicolumn{2}{|c|}{$\begin{array}{l}\text { Notes: (1) All micro data estimates include year-industry effects } \\
\text { (2) COMPUSTAT data are aggregated using industries and asset classes as } \\
\text { defined in the IRS Statistics of I ncome Aggregate estimates are not } \\
\text { substantially affected by the exclusion of small firms. } \\
\text { (3) "Meltzer industries" are wholesale trade, retail trade, and some } \\
\text { manufacturing (SIC codes } 20,22,24,26,28,29,30,32,33,35,50-59) \text {. } \\
\text { (4) } 1957 \text { Cross-industry estimate from Meltzer (1963a) }\end{array}$} \\
\hline
\end{tabular}

The first row of Table 8 displays the estimated sales elasticity from column 5 of Table 1. The second row displays the estimate from column 6 of Table 1, which is obtained by excluding 6650 firm-years with sales less than one million 1987 dollars and years outside the interval 1961-92. Doing so increases the estimated sales elasticity by 0.09 to 0.83 . Since Meltzer (1963a) studies only a minority of the industries sampled by COMPUSTAT, the third row reports the sales elasticity estimated with COMPUSTAT microdata from Meltzer's industries only; the estimate seems insensitive to this sample restriction. The sample is then aggregated by industry to 
"simulate" the IRS-type data and the resulting estimate of 0.96 is reported in the fourth row of the Table. Since previous results suggest that the measurement error does not affect the micro data estimates, it appears that the larger elasticity reported in fourth row is due to aggregation bias. IRS data by industry and asset class from 1963, the latest year for which the Statistics of I ncomecan be used to replicate Meltzer's study, is used to produce the estimate of 0.99 reported in the fifth row. The final row of the Table reports Meltzer's estimate from 1957 IRS data which, when compared with the previous two rows, suggests that the sales elasticity may have fallen over time. .9,30 $^{29}$

The present study of firms has produced some new empirical results. First, it seems clear that there are scale economies in the holding of money by firms. Second, aggregation and selection appears to bias upwards estimates of the sales elasticity. Third, the demand for money by firms depends in an important way on the value of time. Fourth, it appears that the dynamics of firm cash holdings is consistent with stochastic optimal inventory models although this is a topic which was not carefully studied in the current paper.

A list of variables may have been omitted from my basic money demand equation, including technology parameters, cross-sectional measures of the price level, business cycle variables, selection effects, and measurement errors. It appears from Tables 1 - 4 that the agricultural area variables and the year-industry effects proxy sufficiently well for the omitted variables. Estimates such as those displayed in column 5 of Table 1 therefore lead me to bel ieve that the sales and wage elasticities of the demand for money by firms are approximately 0.75 .

\footnotetext{
${ }^{29}$ Since interest rates increased dramatically from the early 1960's to the 1970's, inventory models predict that the scale elasticity would fall. See Mulligan and Sala-i-Martin (1996) for a derivation of this result.

${ }^{30}$ The IRS estimates are computed as follows: regression estimates are obtained across asset classes within each industry and then these estimates are averaged across industries.
} 


\section{Estimates of the Demand for Liquid Assets}

Although the sum of currency and demand deposits constitutes a more preferable measure of "money" than does liquid assets, one can learn something about firm's demand for money by studying their demand for liquid assets. The COM PUSTAT measure of liquid assets, "cash and short term investments," adds several marketable securities to the firms currency and demand deposits. The additions include holdings of government bonds, time deposits, and commercial paper.

Table 9 displays OLS estimates of the money demand equation (3)', using the log of "cash and short-term investments" as the dependent variable. Only year effects and log sales are included as regressors in column 1; the sales elasticity for liquid assets (0.768) is close to the sales elasticity for $M 1$ reported in column 1 of Table 1 (0.752). The wage elasticities reported in columns 2-4 are higher - about 1.0. However, inclusion of year-industry effects reduces estimates of the wage elasticity of the demand for liquid assets from 1.0 to 0.82 . 
Scale Economies and the Value of Time (12/97) - 38

\begin{tabular}{|c|c|c|c|c|c|c|c|c|}
\hline independent & \multicolumn{8}{|c|}{ dependent variable: $\log$ (cash $\&$ short-term investments) } \\
\hline log sales & $\begin{array}{c}0.768 \\
(0.002)\end{array}$ & $\begin{array}{c}0.758 \\
(0.002)\end{array}$ & $\begin{array}{c}0.758 \\
(0.002)\end{array}$ & $\begin{array}{c}0.758 \\
(0.002)\end{array}$ & $\begin{array}{c}0.783 \\
(0.002)\end{array}$ & $\begin{array}{c}0.773 \\
(0.002)\end{array}$ & $\begin{array}{c}0.773 \\
(0.002)\end{array}$ & $\begin{array}{c}0.773 \\
(0.002)\end{array}$ \\
\hline log wage & & $\begin{array}{l}1.128 \\
(0.028)\end{array}$ & $\begin{array}{l}1.048 \\
(0.031)\end{array}$ & $\begin{array}{l}1.043 \\
(0.031)\end{array}$ & & $\begin{array}{c}0.845 \\
(0.026)\end{array}$ & $\begin{array}{l}0.822 \\
(0.029)\end{array}$ & $\begin{array}{c}0.821 \\
(0.029)\end{array}$ \\
\hline $\begin{array}{l}\text { agricultural } \\
\text { area }\end{array}$ & & & $\begin{array}{l}-3.04 \\
(0.46)\end{array}$ & $\begin{array}{l}-3.13 \\
(0.45)\end{array}$ & & & $\begin{array}{l}-0.95 \\
(0.42)\end{array}$ & $\begin{array}{l}-1.02 \\
(0.42)\end{array}$ \\
\hline $\begin{array}{l}\text { agricultural } \\
\text { area }^{2}\end{array}$ & & & $\begin{array}{l}10.30 \\
(1.49)\end{array}$ & $\begin{array}{l}10.49 \\
(1.50)\end{array}$ & & & $\begin{array}{c}4.10 \\
(1.47)\end{array}$ & $\begin{array}{c}4.27 \\
(1.48)\end{array}$ \\
\hline temporary u.i. & & & & $\begin{array}{l}-0.33 \\
(0.09)\end{array}$ & & & & $\begin{array}{l}-0.18 \\
(0.09)\end{array}$ \\
\hline temporary u.i. ${ }^{2}$ & & & & $\begin{array}{c}0.02 \\
(0.26)\end{array}$ & & & & $\begin{array}{c}0.53 \\
(0.24)\end{array}$ \\
\hline year effects & yes & yes & yes & yes & yes & yes & yes & yes \\
\hline $\begin{array}{l}\text { year-industry } \\
\text { effects? }\end{array}$ & no & no & no & no & yes & yes & yes & yes \\
\hline $\bar{R}^{2}$ & .56 & .56 & .56 & .56 & .65 & .65 & .65 & .65 \\
\hline std error & 1.65 & 1.64 & 1.64 & 1.64 & 1.48 & 1.47 & 1.47 & 1.47 \\
\hline $\mathrm{N}$ & 144382 & 144382 & 144382 & 144382 & 144382 & 144382 & 144382 & 144382 \\
\hline \multicolumn{9}{|c|}{$\begin{array}{l}\text { Notes: (1) "cash and short-term investments" is "cash" plus many other marketable securities. See text for a } \\
\text { detailed definition } \\
\text { (2) "agricultural area" is agriculture's share of personal income in the county where the firm is headquartered } \\
\text { (3) "wage" is wages and salaries per empl oyee in the county where the firm is headquartered } \\
\text { (4) "temporary u.i" is unemployment insurance benefits per worker in the county where the firm is } \\
\text { headquartered minus that county's average u.i. for the years } 1969-90 \\
\text { (5) year effects are estimated in every regression } \\
\text { (6) N is the number of firm-year cells included in the regression } \\
\text { (7) standard errors are displayed in parentheses }\end{array}$} \\
\hline
\end{tabular}

It appears from Table 9 that the wage and sales elasticities of the demand for the more broad measure of money are only slightly larger than those for the more narrow measure. 


\section{Implications for Aggregate Data}

The firm-level data indicate that there are economies of scale in the holding of money in the sense that the production parameter $\beta$ is less than one. An important feature of the firmlevel data is that the price of money substitutes (in particular, time) need not be correlated with sales. It is straight-forward, therefore, to estimate separate scale and cross-price elasticities of money demand with the firm data. Aggregate time series data, on the other hand, have the unpleasant feature that wages and income are highly correlated. ${ }^{31}$

Might the findings for firms' money demand functions apply to an aggregate money demand equation? This question can be answered in three parts. First, there are reasonable conditions under which a micro level demand function such as (3)' can be aggregated into a demand function for the entire firm sector. For example, suppose that $y_{i t}, w_{i t}$, and $A_{i t}$ are lognormally distributed in every cross-section of firms. Then (3)' implies that the demand for money by the entire firm sector in year $\mathrm{t}$ is (6):

$$
\log \bar{m}_{t}=\beta \log \bar{y}_{t}-\gamma \log R_{t}+\pi_{\phi}\left(\Psi_{\phi}-\gamma\right) \log \frac{\bar{w}_{t}}{R_{t}}-(1-\gamma) \log \bar{A}_{t}+(\text { covariances })+(\text { constant })
$$

where overbars indicate cross-firm averages. Second, one must argue that sales per firm is roughly proportional to GNP (if GNP is to be the scale variable in the aggregate equation). ${ }^{32}$ Third, households must have demand functions that are similar to those for firms (ie, their demand functions must have similar scale and wage elasticities) or households must hold a relatively small fraction of the aggregate money stock. ${ }^{33}$

${ }^{31}$ I ncome and wages are like to be correlated in cross-sections of regional aggregates as well.

32 Or one can introduce another variable into the aggregate equation, the ratio of sales to GNP. See Fujiki and Mulligan (1996) for a more detailed discussion of this and other aggregation issues.

Sales per firm may grow more slowly than GNP. According to the IRS Statistics of Income, business recei pts per corporate income tax return grew by $0.2 \%$ per year during the 1960 s, $0.6 \%$ per year during the 1970 s and fell by 3.4\% per year during the period 1980-87. Sales per firm displays a slight downward trend in my COMPUSTAT sample.

33 Some cross-section studies of househol ds such as Bomberger (1993) and Lee (1964), have found evidence of scale economies. To my knowledge, separate wage elasticities are not 
There is some evidence that firms hold a substantial fraction of M1. The Federal Reserve's Demand Deposit Ownership Survey (DDOS) separately tabulates the ownership of demand deposits at commercial banks by financial firms, nonfinancial firms, households, foreigners, and "others." One sees in Figure 8 that, according to the DDOS, nonfinancial firms hold at least 50\% more demand deposits than do households. ${ }^{34}$ By the 1980's, firms had accumulated almost twice as many demand deposits as households had. However, another source gives a different picture. The Federal Reserve's Flow of Funds (FOF) reports the ownership of currency plus demand deposits by seven major sectors: (1) households, (2) nonfinancial business, (3) state and local governments, (4) U.S. government, (5) foreigners, (6) monetary authorities, monetary pools, and federally sponsored credit agencies, and (7) financial business. According to the FOF, firms hold less than half of currency and demand deposits as do households. A timeseries of the nonfinancial business/household ratio is displayed in Figure 8 as a dashed line. The fraction of M1 held by firms has not changed much in the 1980's according to the flow of funds. As the aggregate of DDOS numbers correspond much more closely to aggregate M 1 than to the FOF numbers, it is likely that the DDOS are more accurate and one can conclude than firms do hold a substantial fraction of $\mathrm{M} 1 .^{35}$

estimated, nor are there any attempts to correct for the regression effect.

${ }^{34}$ The second quarter of 1981 is missing from the DDOS series. The missing data is shown as a hole in the solid line in Figure 10.

${ }^{35}$ There are several reasons to prefer the DDOS ratio of firm to household demand deposits as an estimate of the ratio of firm to household M1. First, FOF estimates are for a single day (the last day of the quarter) whereas the DDOS intends to measure daily average balances for the last month of the quarter. Second, FOF appears to allocate all outstanding currency to the household sector - an amount equal to $\$ 1250$ per person in 1994 (U.S. Council of E conomic Advisors, 1994, Table B-69). For a discussion of these and other problems with FOF estimates of M1, see Board of Governors (1971). 


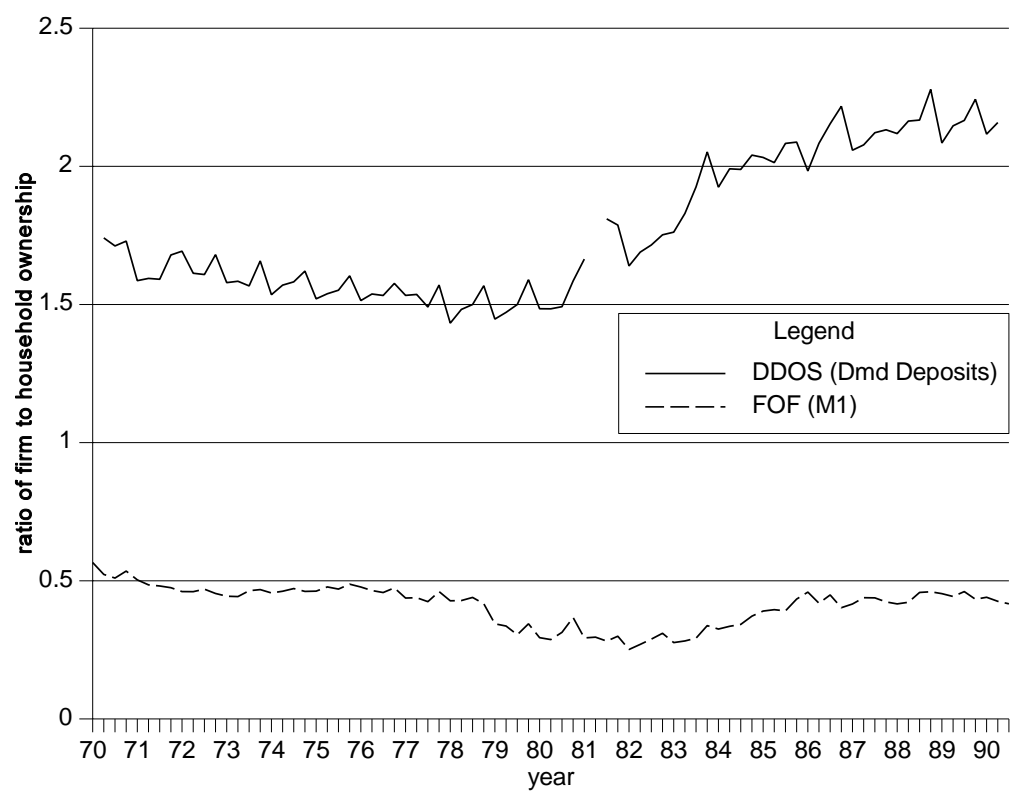

Figure 8 Nonfinancial business money holdings as a fraction of household holdings

I also compare changes over time in sales velocity of the sample COMPUSTAT firms with changes in the velocity of M1. Figure 9 shows that the sales velocity of the sample firms (solid line) increased at about the same rate as GNP velocity (dashed line) during the 1970's. ${ }^{36}$ The 1980's were different: GNP velocity was fairly stable as compared to the sales velocity of the sample firms.

${ }^{36}$ Remember from figure 2 that not many firms are in the sample before 1969. 


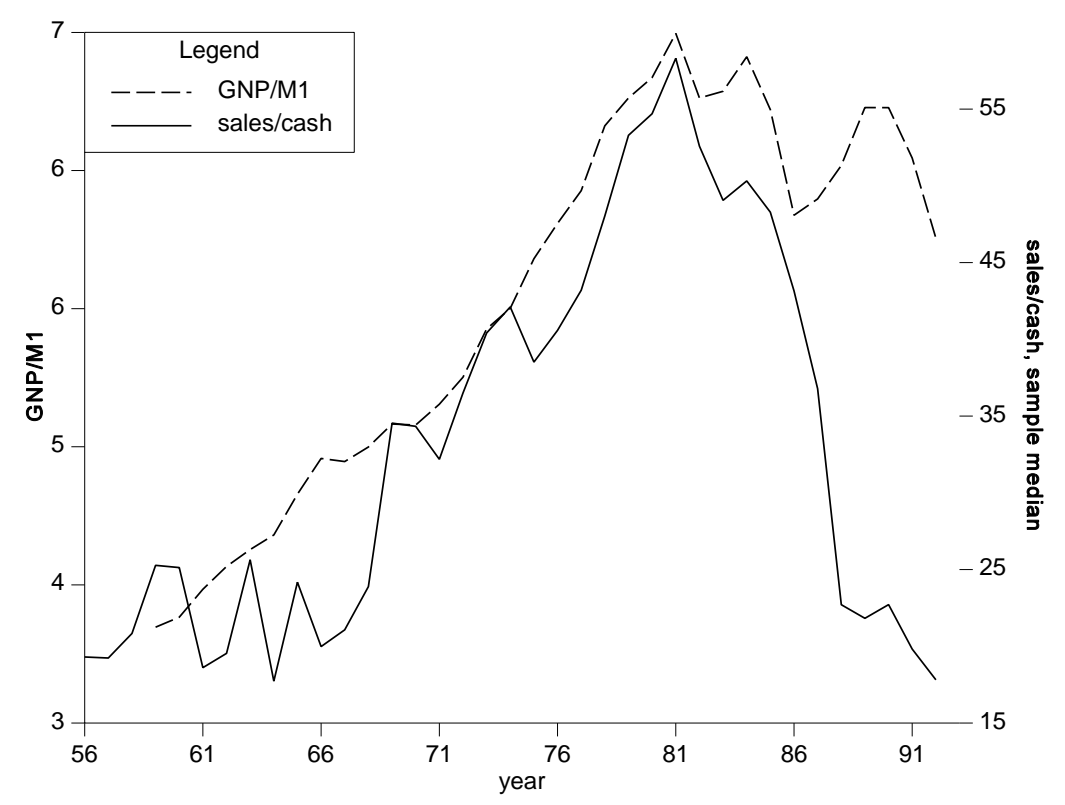

Figure 11 M 1 GNP Velocity vs. Micro Sales Velocity

This paper has estimated a scale elasticity of about 0.75 and a wage elasticity of about 0.70 for firms, estimates which should be indicative of the scale and wage elasticities of an aggregate money demand function. The estimates are consistent with the notion that there are economies of scale in the holding of money, but do not imply that velocity will increase over time (as income grows). Consider, as an approximation, that sales per firm, aggregate sales, income, and wages grow at the same rate over time. The estimates imply that, for a given level of financial sophistication, the income elasticity estimated from a time series (say by regressing log money on log income) might be 1.4 or 1.5 . An income elasticity of 1.5 or 1.6 might be found if sales per firm grew at half the rate of GNP. Friedman (1959), using time series data for the period 1870-1954, finds an income elasticity of 1.8. F riedman and Schwartz (1982) later revised this estimate to 1.2 (effectively by ignoring the period 1870-1903, see their p. 243). The late nineteenth and early twentieth century time series data appears to be roughly consistent with my findings. Lucas (1988) and Meltzer (1963b), however, argue that one obtains an income elasticity close to one for time series data for the twentieth century.

The Lucas/Meltzer findings can be reconciled with those of Friedman/Schwartz if there 
is an omitted financial technology variable such as the $A_{i t}$ of my model. During the early twentieth century, there may have been little secular trend of $A_{i t}$. Later in the twentieth century, better substitutes for money were devel oped or made cheaper to use. NOW accounts, automatic teller machines, and credit cards might be considered to be modern examples. This conjecture is consistent with regional comparisons of money and aggregate income, where differences in financial technology are less serious. Mulligan and Sala-i-Martin (1992) compare aggregates of income and demand deposits across states for the years 1929-90 and find income elasticities between 1.1 and 1.5. Their findings are both consistent with the cross-firm evidence presented here and with the idea that secular trends in financial sophistication bias time series estimates, especially those in the twentieth century.

I conclude with an estimate of the interest elasticity. Although the time dimension of my data set is not very large (I have 24 large annual cross-sections and five smaller ones), changes in the nominal interest rate over the period are large enough to permit fairly precise estimation of an interest elasticity. The first estimation step is to regress log cash on log sales, log wage, the agriculture variables, and year-industry effects as is done in col umn 5 of Table 1. For each year, I compute the median residual from this regression (where the "residual" includes the industry-year effects). Under the hypothesis that the level of financial sophistication is not correlated with the nominal interest rate, a consistent estimate of - $[\gamma+$ $\left.\pi_{\phi}\left(\psi_{\phi}-\gamma\right)\right]$ can be obtained by regressing the annual time series of median residuals on the log of the nominal interest rate. Using annual averages of Moody's AAA corporate bond yield, the coefficient in this regression is -1.20 (s.e. $=0.27$ ). ${ }^{37}$ An estimate of gamma is obtained by adding the cross-sectional estimate of the wage elasticity, $\pi_{\phi}\left(\psi_{\phi}-\gamma\right)$, to the time series regression coefficient. 0.74 is the estimate of the wage elasticity reported in column 5 of Table 1, implying an estimate of 0.46 for $\gamma$.

\footnotetext{
${ }^{37}$ Three other interest rates - the six month commercial paper rate, the three month Treasury Bill rate, and the six month Treasury Bill rate - result in regression coefficients of $-0.67,-0.68$, and -0.74 respectively (standard errors are 0.17 , somewhat smaller than the 0.27 obtained using the AAA bond yield). These imply near zero estimates of $\gamma$. Since the AAA bond yield fit the best and has been used in other time series studies, I use it for the results reported in the text.
} 


\section{Appendix: Sample Characteristics}

This appendix displays in Table A-1 means and standard deviations of the variables used in the analysis.

\begin{tabular}{|c|c|c|c|c|c|}
\hline \multicolumn{6}{|c|}{ Table A-1: Summary Statistics } \\
\hline \multicolumn{2}{|l|}{ Variable } & Mean & Std Dev & Min & Max \\
\hline \multirow[t]{2}{*}{ cash } & level & 43 & 337 & 0.0008 & 18262 \\
\hline & $\log$ & 0.49 & 2.49 & -7.10 & 9.81 \\
\hline \multirow{2}{*}{ liquid assets } & level & 101 & 865 & 0.0008 & 53046 \\
\hline & $\log$ & 1.14 & 2.61 & -7.10 & 10.88 \\
\hline \multirow[t]{2}{*}{ sales } & level & 668 & 3385 & 0.0008 & 143802 \\
\hline & $\log$ & 3.95 & 2.50 & -7.07 & 11.88 \\
\hline \multirow{2}{*}{$\begin{array}{l}\text { county avg. annual } \\
\text { earnings }\end{array}$} & level & 23283 & 3838 & 9608 & 41879 \\
\hline & $\log$ & 10.04 & 0.16 & 9.17 & 10.64 \\
\hline \multicolumn{2}{|c|}{$\begin{array}{l}\text { county farming share of personal } \\
\text { income }\end{array}$} & 0.005 & 0.017 & -0.112 & -0.724 \\
\hline \multicolumn{2}{|c|}{ county u.i. per worker } & 156.81 & 135.49 & 0 & 2414 \\
\hline \multicolumn{2}{|c|}{$\begin{array}{l}\text { county u.i. per worker minus } 69- \\
90 \text { county mean }\end{array}$} & -3.72 & 104.52 & -608.28 & 1846 \\
\hline \multicolumn{6}{|c|}{$\begin{array}{l}\text { Notes (1) cash, liquid assets, and sales are in millions of } 1987 \$ \text {. } \\
\text { (2) county avg. annual earnings and u.i. per worker are in } 1987 \$ . \\
\text { (3) the GNP implicit price deflator is used to convert all current \$ to } 1987 \text {. } \\
\text { (4) sample is the 108,738 firm-years used to compute the regressions in Tables } 1 \text { and } 4 . \\
\text { (5) Nine firm-years in the 108,738 firm-year sample do not report liquid assets. } \\
\text { (6) Liquid assets is "cash and short-term investments." See Section II for more precise } \\
\text { definitions of the variables. }\end{array}$} \\
\hline
\end{tabular}

Figure A-1 illustrates some relationships between counties and firms in the 108,738 firm-year sample. The figure is a histogram with the fraction of firm-years on the vertical axis and the number of firms in the same county in the same year on the horizontal axis. For example, the leftmost bar in the figure shows that nearly $25 \%$ of the 108,738 data points used to compute the regressions in Table 1 share a county with nine or fewer other firms in that year (ie, almost 25\% 
are in county-year cells of size 10 or less). Another $50 \%$ of the data points share a county with 100 or fewer firms in the same year.

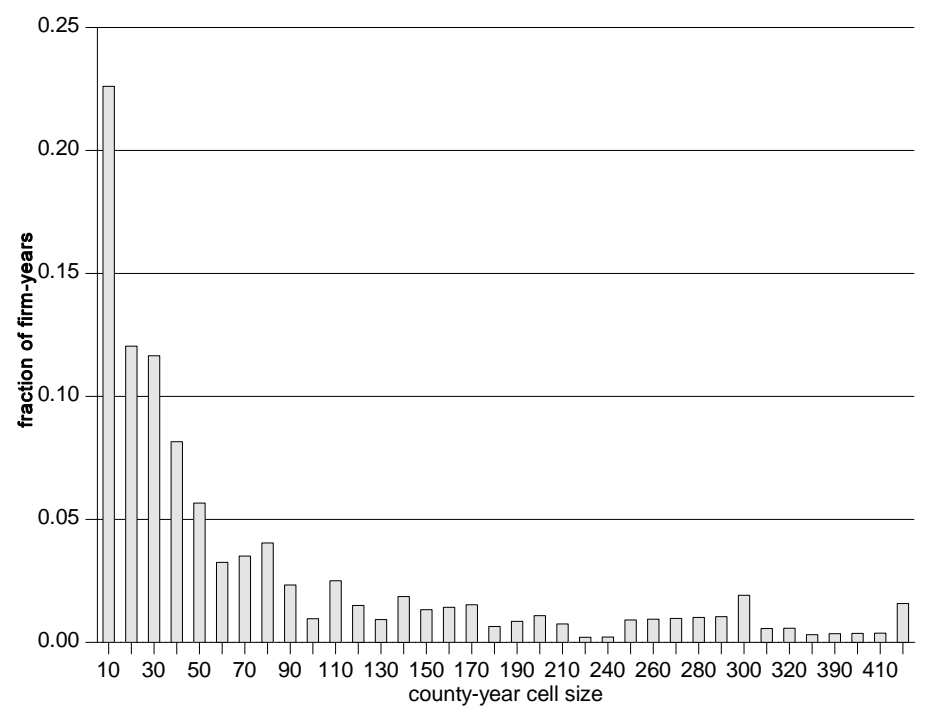

Figure A-1 County-Y ear Cell Sizes

$$
\mathrm{N}=108,738
$$

Table A-2 lists the SIC two-digit industries that appear in the sample in at least one year. 


\begin{tabular}{|c|c|c|c|}
\hline \multicolumn{4}{|c|}{ Table A-2: Two-Digit SIC Codes } \\
\hline \multirow[t]{2}{*}{ SIC Code } & \multicolumn{2}{|c|}{ Number of Firm-Years } & \multirow[t]{2}{*}{ Industry Name } \\
\hline & number & $\%$ & \\
\hline 1 & 273 & 0.25 & AGRICULTURE PRODUCTION-CROPS \\
\hline 2 & 141 & 0.13 & AGRICULTURE PRODUCTION-LIVESTOCK \\
\hline 7 & 90 & 0.08 & AGRICULTURAL \& VETERINARY SERVICES \\
\hline 8 & 21 & 0.02 & FORESTRY \\
\hline 10 & 611 & 0.56 & METAL MINING \\
\hline 12 & 234 & 0.22 & COAL MINING \\
\hline 13 & 4801 & 4.42 & OIL \& GAS EXTRACTION \\
\hline 14 & 259 & 0.24 & MNG, QUARRY NONMTL MINERALS \\
\hline 15 & 1147 & 1.05 & GENERAL CONTRACTORS \& OPERATIVE BUILDERS \\
\hline 16 & 403 & 0.37 & HEAVY CONSTR-NOT BLDG CONSTR \\
\hline 17 & 347 & 0.32 & CONSTRUCTION-SPECIAL TRADE \\
\hline 20 & 3195 & 2.94 & FOOD \& KINDRED PRODUCTS \\
\hline 21 & 184 & 0.17 & TOBACCO PRODUCTS \\
\hline 22 & 1583 & 1.46 & TEXTILE MILL PRODUCTS \\
\hline 23 & 1670 & 1.54 & APPAREL \& OTHER UNFINISHED TEXTILE PRODUCTS \\
\hline 24 & 936 & 0.86 & LUMBER \& WOOD PRODUCTS, EXCEPT FURNITURE \\
\hline 25 & 886 & 0.81 & FURNITURE \& FIXTURES \\
\hline 26 & 1359 & 1.25 & PAPER \& ALLIED PRODUCTS \\
\hline 27 & 2198 & 2.02 & PRINTING, PUBLISHING \& ALLIED INDUSTRIES \\
\hline 28 & 4926 & 4.53 & CHEMICALS \& ALLIED PRODUCTS \\
\hline 29 & 886 & 0.81 & PETROLEUM AND COAL PRODUCTS \\
\hline 30 & 1823 & 1.68 & RUBBER \& MISC PLASTICS PRODUCTS \\
\hline 31 & 508 & 0.47 & LEATHER \& LEATHER PRODUCTS \\
\hline 32 & 1234 & 1.13 & STONE, CLAY, GLASS \& CONCRETE PRODUCTS \\
\hline 33 & 2088 & 1.92 & PRIMARY METAL INDUSTRIES \\
\hline 34 & 3133 & 2.88 & FABRICATED METAL PRODUCTS \\
\hline 35 & 7901 & 7.27 & MACHINERY \& COMPUTING EQUIPMENT \\
\hline 36 & 7197 & 6.62 & ELECTRICAL MACHINERY, EQUIPMENT \& SUPPLIES \\
\hline 37 & 2932 & 2.7 & TRANSPORTATION EQUIPMENT \\
\hline 38 & 6130 & 5.64 & PROFESSIONAL AND PHOTOGRAPHIC EQ, \& WATCHES \\
\hline 39 & 1339 & 1.23 & MISCELLANEOUS MANUFACTURING INDUSTRIES \\
\hline 40 & 344 & 0.32 & RAILROADS \\
\hline 41 & 50 & 0.05 & BUS SERVICE \& URBAN TRANSIT \\
\hline 42 & 940 & 0.86 & TRUCKING, WAREHOUSING, \& STORAGE \\
\hline 44 & 319 & 0.29 & WATER TRANSPORTATION \\
\hline 45 & 932 & 0.86 & AIR TRANSPORTATION \\
\hline 46 & 68 & 0.06 & PIPE LINES, EXCEPT NATURAL GAS \\
\hline 47 & 339 & 0.31 & SERVICES INCIDENTAL TO TRANSPORTATION \\
\hline 48 & 2794 & 2.57 & COMMUNICATIONS \\
\hline 49 & 1589 & 1.46 & UTILITIES \& SANITARY SERVICES \\
\hline
\end{tabular}




\begin{tabular}{|c|c|c|c|}
\hline 50 & 3564 & 3.28 & WHOLESALE TRADE - DURABLE GOODS \\
\hline 51 & 1978 & 1.82 & WHOLESALE TRADE - NONDURABLE GOODS \\
\hline 52 & 466 & 0.43 & BLDG MATL,HARDWR,GARDEN-RETL \\
\hline 53 & 1514 & 1.39 & DEPARTMENT, VARIETY, \& MISC MERCHANDISE STORES \\
\hline 54 & 1219 & 1.12 & FOOD STORES \\
\hline 55 & 279 & 0.26 & AUTO DEALERS \& SERVICE STATIONS \\
\hline 56 & 942 & 0.87 & APPAREL AND ACCESSORY STORES \\
\hline 57 & 642 & 0.59 & HOME FURNITURE \& EQUIP STORE \\
\hline 58 & 1929 & 1.77 & EATING \& DRINKING PLACES \\
\hline 59 & 1796 & 1.65 & MISCELLANEOUS RETAIL \\
\hline 60 & 3490 & 3.21 & BANKS \& SAVINGS INSTITUTIONS \\
\hline 61 & 2144 & 1.97 & CREDIT AGENCIES \\
\hline 62 & 963 & 0.89 & SECURITY \& COMMODITY BROKERAGE \\
\hline 63 & 245 & 0.23 & INSURANCE CARRIERS \\
\hline 64 & 409 & 0.38 & INSURANCE AGENTS, BROKERS, \& SERVICE \\
\hline 65 & 2305 & 2.12 & REAL ESTATE \\
\hline 67 & 3591 & 3.3 & INVESTMENT COMPANIES \\
\hline 70 & 778 & 0.72 & HOTELS, MOTELS, AND LODGING PLACES \\
\hline 72 & 402 & 0.37 & PERSONAL SERVICES \\
\hline 73 & 5286 & 4.86 & BUSINESS SERVICES \\
\hline 75 & 323 & 0.3 & AUTO REPAIR,SERVICES,PARKING \\
\hline 76 & 77 & 0.07 & MISC REPAIR SERVICES \\
\hline 78 & 885 & 0.81 & MOTION PICTURES \& VIDEOTAPE PRODUCTION \& DISTRIBUTION \\
\hline 79 & 1275 & 1.17 & ENTERTAINMENT \& RECREATION SERVICES \\
\hline 80 & 1640 & 1.51 & HEALTH SERVICES \\
\hline 81 & 8 & 0 & LEGAL SERVICES \\
\hline 82 & 248 & 0.23 & EDUCATIONAL SERVICES \\
\hline 83 & 95 & 0.09 & SOCIAL SERVICES \\
\hline 84 & 12 & 0.01 & MUSEUMS, ART GALLERIES, \& ZOOS \\
\hline 86 & 9 & 0 & MEMBERSHIP ORGANIZATIONS \\
\hline 87 & 1750 & 1.61 & ENGR,ACC,RESH,MGMT,REL SVCS \\
\hline 89 & 13 & 0.01 & PROFESSIONAL \& RELATED SERVICES \\
\hline 99 & 651 & 0.6 & INDUSTRY NOT REPORTED \\
\hline TOTAL & 108738 & 100.01 & \\
\hline
\end{tabular}




\section{References}

Allais, Maurice. E conomieet Intérêt. Paris: Imprimerie Nationale, 1947.

Baumol, William J . "The Transactions Demand for Cash: An Inventory Theoretic Approach." QuarterlyJ ournal of E conomics. 66, November 1952.

Board of Governors of the Federal Reserve System. Federal ReserveBulletin. various issues. Board of Governors of the Federal Reserve System. "Survey of Demand Deposit Ownership." Federal ReserveBulletin. 57, J une 1971: 456-67.

Board of Governors of the Federal Reserve System. Introduction to the Flow of Funds. Washington D.C.: Board of Governors of the Federal Reserve System Publications, J une 1980.

Bomberger, William A. "Income, Wealth and Household Demand for Deposits." American Economic Review. 83(4), September 1993: 1034-44.

Faig, Miquel. "Characterization of the Optimal Tax on Money When It Functions as a Medium of Exchange." J ournal of Monetary E conomics. 22(1), J uly 1988: 137-48.

Feenstra, Robert C. "Functional Equivalence between Liquidity Costs and the Utility of Money." J ournal of Monetary E conomics. 17, 1986: 271-91.

Feige, Edgar L. TheDemand for Liquid Assets: A Temporal Cross-Section Analysis. Englewood Cliffs, NJ : Prentice Hall, 1964.

Fischer, Stanley. "Money and the Production Function." Economic Inquiry. 12, 1974: 517-33. Frazer, W. J ., J r. "The Financial Structure of Manufacturing Corporations and the Demand for Money: Some Empirical Findings." J ournal of Political Economy. 72, April 1964.

Friedman, Milton. A Theory of theConsumption Function. Princeton, NJ : Princeton University Press, 1957.

Friedman, Milton. "The Demand for Money: Some Theoretical and Empirical Results." J ournal of Political Economy. 67(4), 1959. Reprinted in Milton Friedman, ed. The Optimum Quantity of Money and Other Essays. Chicago: Aldine Publishing, 1969.

Friedman, Milton and Anna J acobson Schwartz. Monetary Trends in the United States and United Kingdom: Their Relation to Income, Prices, and Interest Rates, 1867-1975. Chicago: University of Chicago Press, 1982.

Fujiki, Hiroshi and Casey B. Mulligan. "Production, Financial Sophistication, and the Demand for Money by Households and Firms." Bank of J apan Monetary and Economic Studies. 
14(1), J uly 1996: 65-103.

Goldfeld, Steven M. and Lester V. Chandler. The Economics of Money and Banking. New York: Harper \& Row Publishers, Inc., 1986.

Griliches, Zvi and J erry A. Hausman. "Errors in Variables in Panel Data." J ournal of Econometrics. 31(1), February 1986: 93-118.

Heckman, J ames J . "Sample Selection Bias as a Specification Error." Econometrica. 47(1), J anuary 1979: 153-61.

Karni, E di. "The Transactions Demand for Cash: Incorporation of the Value of Time into the Inventory Approach." J ournal of Political Economy. 81, 1973: 1216-1225.

Lee, Tong Hun. "Income, Wealth, and the Demand for Money: Some Evidence from Cross-Section Data." J ournal of the American Statistical Association. 59, September 1964: 746-62.

Lucas, Robert E., J r. "Money Demand in the United States: A Quantitative Review." Karl Brunner and Bennett T. McCallum, eds. Money, Business Cycles, and Exchange Rates: Essays in Honor of Allan H. Meltzer. Carnegie-Rochester Series on Public Policy, 29, 1988.

Maddala, G. S. and Robert C. Vogel. "The Demand for Money: A Cross-Section Study of Business Firms: Comment." Quarterly J ournal of Economics. 79(1), February 1965: $153-65$.

Meltzer, Allan H. "The Demand for Money: A Cross-Section Study of Business Firms." QuarterlyJ ournal of Economics. 77(3), August 1963a: 405-22.

Meltzer, Allan H. "The Demand for Money: Evidence from Time Series." J ournal of Political Economy. 71(3), 1963b: 219-46.

Miller, Merton M. and Daniel Orr. "A Model of the Demand for Money by Firms." Quarterly J ournal of Economics. 80, August 1966: 413-35.

Mulligan, Casey B. "Scale Economies, the Value of Time, and the Demand for Money: Longitudinal Evidence from Firms." J ournal of Political Economy. 105(5), October 1997: 1061-79.

Mulligan, Casey B. and Xavier Sala-i-Martin. "U.S. Money Demand: Surprising CrossSectional Estimates." Brookings Papers on Economic Activity. 2, 1992: 285-343.

Mulligan, Casey B. and Xavier Sala-i-Martin. "Adoption of Financial Technologies: Implications for Money Demand and Monetary Policy." NBER Working Paper Series 
\#5504, March 1996a.

Radecki, Lawrence J . and Cecily C. Garver. "The Household Demand for Money: Estimates from Cross-sectional Data." Federal ReserveBank of New York Quarterly Review. 12(1), Spring 1987: 29-34.

Standard \& Poor's. COMPUSTAT. New York: McGraw-Hill, August 30, 1993.

Tobin, J ames. "The Interest Elasticity of the Transactions Demand for Money." Review of Economics and Statistics. 38, August 1956.

United States Council of Economic Advisors. Economic Report of the President. Washington, D.C.: U.S. Government Printing Office, February 1994.

United States Department of Commerce, Bureau of Economic Analysis. Regional Economic Information System. Washington: B.E.A. Regional E conomic Measurement Division, 1992.

United States Department of the Treasury, Internal Revenue Service. Statistics of IncomeCorporation IncomeTax Returns. U.S. Government Printing Office, various issues.

Vogel, Robert C. and G. S. Maddala. "Cross-Section Estimates of Liquid Asset Demand by Manufacturing Corporations." J ournal of Finance. 22, 1967: 557-575.

Whalen, Edward L. "A Cross-Section Study of Business Demand for Cash." J ournal of Finance 20(3), September 1965: 423-43. 